\title{
NATURE v. NURTURE: CHILDREN LEFT FATHERLESS AND FAMILY-LESS WHEN NATURE PREVAILS IN PATERNITY ACTIONS
}

\author{
Niccol Kording ${ }^{*}$
}

One hundred years from now [i]t will not matter [w] hat kind of car I drove, [w] hat kind of house I lived in, [h]ow much money I had in the bank . . . But the world may be . . . a little better because I was important in the life of a child. ${ }^{1}$

Those words describe the feeling many parents get from parenthood and from being part of a family, regardless of whether the child is their biological offspring, stepchild, surrogate child, or adopted child. All these families and children born of biological connections or traditional families enjoy some protection under statutory or common law paternity or parentage laws. ${ }^{2}$ The Uniform Parentage $\mathrm{Act}^{3}$ and similar paternity laws protect traditional families under the marital or legitimacy presumption, which provides that children

* Associate Professor of Law and Director of Advocacy at Western State University College of Law. Special thanks to Connie Hood and Paula Manning for their support and comments.

1. Margaret Fishback Powers, The Heart of a Child, in Margaret Fishback Powers, A Heart for Children Inspirations for Parents And Their Children (1995), available at http://www. harpercollinsreligious.com/au/books/features/1863716076.htm.

2. Surrogate parents are protected by surrogacy statutes. See 750 Ill. Comp. Stat. Ann. 45/6(a) (Lexis 1999); Nev. Rev. Stat. Ann. 126.045 (Michie 1998); Wash. Rev. Code Ann. §§ 26.26.101(2)(f), 26.26.210-26.26.260 (West 1997). Adopted children are also protected under the legitimacy or adoption statutes. See Del. Code Ann. tit. 13, § 803(3) (1999); Haw. Rev. Stat. Ann. § 584-3 (Lexis 1999); 750 Ill. Comp. Stat. Ann. 45/4(3) (Lexis 1999); Minn. Stat. Ann. § 257.54 (West 2003); Mo. Ann. Stat. $\S 210.819$ (3) (West 1996); Mont. Code Ann. § 40-6-104 (2003); Tex. Fam. Code AnN. § 160.201(a)(4) (Vernon 2002); Wash. Rev. Code Ann. § 26.26.101(2) (West 1997); Wyo. Stat. Ann. § 14-2-501(b)(iv) (LexisNexis 2003). In addition, biological children of unmarried parents are protected under the Uniform Parentage Act and similar state statutes. See Del. Code Ann. tit. 13, § 804(a)(6) (1999); Haw. Rev. Stat. AnN. §584-4(a)(5) (Lexis 1999); 750 Ill. Comp. Stat. Ann. 45/11 (Lexis 1999); Ind. Code AnN. $\S 31-14-7-1$ (3) (Michie 1997); Ky. Rev. Stat. Ann. § 406.111 (Michie 1999); Md. Code Ann. Fam. Law $\S 5-1029$ (f)(4)(1999); Minn. Stat. Ann. § 257.55(f) (West 2003); Mo. Ann. Stat. § 210.822.1(4) (West 1996); Mont. Code Ann. §§ 40-5-234(3), 40-6-105(f) (2003); Nev. Rev. Stat. Ann. 126.051(1)(e) (Michie 1998); N.M. Stat. AnN. § 40-11-5D (Michie 1978); 23 Pa. Cons. Stat. AnN. § 5104 (West 2001); R.I. Gen. LAws. § 15-8-3(a)(5) (2003); Tex. FAM. Code ANN. §§ 160.502, 160.505 (Vernon 2002); Wash. Rev. Code Ann. § 26.26.570 (West 1991); Wyo. Stat. AnN. §§ 14-2-702, 14-2-705 (LexisNexis 2003). This article does not address stepparent or foster parent families as they are both given some protections under the law and are distinguishable from non-traditional families with one biological parent and one non-biological parent.

3. Unif. Parentage Act $\S 204$ (2000), 9B U.L.A. 14 (Supp. 2003). 
born during a marriage or within the period of gestation thereafter are presumed to be the biological children of the husband and wife. ${ }^{4}$

Either the husband or wife can take specific actions to establish paternity. Biological children, through a guardian, parent, or the state, can bring an action to establish paternity in their fathers. ${ }^{5}$ Biological parents can also voluntarily acknowledge their biological children by filing an acknowledgment with the vital records office of their county. ${ }^{6}$ Many states even provide for ways for fathers to do so at the hospital when the child is born. ${ }^{7}$ Biological parents are given additional legal recognition by simply putting their names on the child's birth certificate, public records and insurance. Furthermore, genetic testing can be used to establish a parental relationship with a biological parent. ${ }^{8}$

4. See Ala.Code $\S 26-17-5$ (a)(1)(Michie 1992); Alaska Rev. Stat. $\$ 18.50 .160$ (d)(LexisNexis 2002); Ariz. Rev. Stat. Ann. § 25-814 (2000); Cal. Fam. Code $§ 7611$ (West 1994); Conn. Gen. Stat. AnN. §19-4-105(1)(a)(West 2003); Del. Code Ann. tit. 13, § 804(a)(1-3)(1999); Haw. Rev. Stat. AnN. $\S$ 584-4(a)(1-3) (Lexis 1999); 750 Ill. Comp. Stat. Ann. 45/5(a)(1) (Lexis 1999); Ind. Code Ann. $\S 31-14-7-1(1)(A)(B)(2)(A)(B)$ (Michie 1997); Ky. Rev. Stat. Ann. $\$ 406.011$ (Michie 1999); Md. Code Ann. Fam. Law § 5-1027(c)(1) (1999); Mass. Gen. Laws AnN. ch. 209C, § 6(a)(1)(2)(3) (West 1998); Minn. Stat. Ann. § 257.55 Subdiv. 1(a)(b)(c) (West 2003); Mo. Ann. Stat. § 210.822.1(1-3) (West 1996); Mont. Code Ann. § 40-6-105(1) (2003); N.J. Stat. Ann. § 9:17-43(a) (West 2002); Nev. Rev. Stat. Ann. 126.051(1) (Michie 1998); N.M. Stat. Ann. § 40-11-5 A(1-3) (Michie 1978); N.D. Cent. Code § 14-17-04 (1997); Ohio Rev. Code Ann. § 3111.03 (West 2000); 23 Pa. Cons. Stat. Ann. $\S 5102$ (b) (West 2001); R.I. Gen. Laws § 15-8-3(a) (2003); Tex. Fam. Code AnN. § 160.204 (Vernon 2002); Wash. Rev. Code Ann. § 26.26.116(1)(a-d) (West 1997); Wyo. Stat. Ann. § 14-2-504(a)(i-iv) (LexisNexis 2003). See also Russell v. Russell, 682 N.E.2d 513, 516 (Ind. 1997); Cochran v. Cochran, 717 N.E.2d 892, 894 (Ind. App. 1999).

5. See Del. Code AnN. tit. 13, § 804(a)(6) (1999); Haw. Rev. Stat. Ann. § 584-4(a)(5) (Lexis 1999); 750 Ill. Comp. Stat. Ann. 45/11 (Lexis 1999); Ind. Code Ann. § 31-14-7-1(3) (Michie 1997); Ky. Rev. Stat. Ann. § 406.111 (Michie 1999); Md. Code Ann. Fam. Law § 5-1029(f)(4) (1999); Minn. Stat. Ann. § 257.55(f) (West 2003); Mo. Ann. Stat. § 210.822.1(4) (West 1996); Mont. Code Ann. $\S \S 40-5-234(3), 40-6-105(f)$ (2003); Nev. Rev. Stat. Ann. 126.051(1)(e)(Michie 1998); N.M. Stat. Ann. $\S 40-11-5$ D (Michie 1978); 23 Pa. Cons. Stat. Ann. § 5104 (West 2001); R.I. Gen. Laws § 15-8-3(a)(5) (2003); Tex. Fam. Code Ann. $\S \S 160.502,160.505$ (Vernon 2002); Wash. Rev. Code AnN. $§ 26.26 .570$ (West 1997); Wyo. Stat. AnN. §§ 14-2-702, 14-2-705 (LexisNexis 2003).

6. See Del. Code Ann. tit. 13, § 804(a)(5) (1999); Haw. Rev. Stat. Ann. § 584-4(a)(6) (Lexis 1999); Ky. Rev. Stat. Ann. § 213.046 (Michie 1998); Minn. Stat. Ann. §§ 257.34, 257.55 Subdiv. 1(e) (West 2003); Mass. Gen. Laws. Ann. ch. 209C, § 6(a)(5) (West 1998); Mont. Code Ann. $\S 40-6-105(1)($ e) (2003); Nev. Rev. Stat. Ann. 126.053 (Michie 1998); N.M. Stat. AnN. § 40-11-5A(5) (Michie 1978); N.D. Cent. Code § 14-17-04(1)(e) (1997); 23 Pa. Cons. Stat. Ann. § 5103 (West 2001); R.I. Gen. Laws $\S 15-8-3(a)$ (4) (2003); Tex. FAM. Code ANN. $\S \S 160.201$ (b)(2), 160.301, 162.302 (Vernon 2002); Wash. Rev. Code Ann. $\S$ 26.25.300, 26.26.305(1)(d) (West 1997); Wyo. Stat. Ann. $\S \S 14-2-601,14-2-602$ (a)(iv) (LexisNexis 2003).

7. See Haw. Rev. Stat. Ann. § 584-3(5)(a) (Lexis 1999); 750 Ill. Comp. Stat. Ann. 45/5(a)(4), 45/6 (Lexis 1999); Mass. Gen. Laws Ann. ch. 209C, § 5(b) (West 1998); 23 Pa. Cons. Stat. Ann. $\S 5103$ (c) (West 2001).

8. See Del. Code Ann. tit. 13, § 804(a)(6) (1999); Haw. Rev. Stat. Ann. § 584-4(a)(5) (Lexis 
The non-traditional family is the only family excluded from the protections of the law. When a father takes part in a non-traditional family where he has no biological relationship to the child, the family is left with scant, if any, protection under paternity laws.

Under most states, a child in this non-traditional family is only protected under procedural statutes that rely on preventing inequities by estopping nonbiological fathers from denying paternity when they were married to the child's mother and knew the child was biologically unrelated to them but still undertook the family relationship and held the child out to the public as their "natural" child, " or when the father was living with the child during either the early years of the child's life and held the child out to the public as his "natural" child. ${ }^{10}$

Children are also defined as natural children based on their biological relationships with their mothers and fathers, rather than their social or psychological relationships. ${ }^{11}$ Even where the non-biological father is married to the mother, the biological father can often squeeze out the non-biological father and assume the role of father, regardless of whether a relationship exists between the child and biological father. ${ }^{12}$

1999); 750 Ill. Comp. Stat. Ann. 45/11 (Lexis 1999); Ind. Code Ann. § 31-14-7-1(3) (Michie 1997); Ky. Rev. Stat. Ann. § 406.111 (Michie 1999); Md. Code Ann. Fam. Law § 5-1029(f)(4) (1999); Minn. Stat. Ann. § 257.55(f) (West 2003); Mo. Ann. Stat. § 210.822.1(4) (West 1996); Mont. Code Ann. $\S \S 40-5-234(3), 40-6-105$ (f) (2003); Nev. Rev. Stat. Ann. 126.051(1)(e) (Michie 1998); N.M. Stat. Ann. $\S$ 40-11-5D (Michie 1978); 23 Pa. Cons. Stat. AnN. § 5104 (West 2001); R.I. Gen. Laws § 15-8-3(a)(5) (2003); Tex. Fam. Code Ann. §§ 160.502, 160.505 (Vernon 2002); Wash. Rev. Code Ann. § 26.26.570 (West 1997); Wyo. Stat. AnN. §§ 14-2-702, 14-2-705 (LexisNexis 2003).

9. See Unif.Parentage Act $\S \S 607,608$ (2000), 9B U.L.A. 25-26 (Supp. 2003); Md. Code Ann. FAM. LAW § 5-1038(a)(2)(ii)(b) (1999); Tex. FAm. Code AnN. § 160.608(a)(1)(2)(Vernon 2002); Wyo. StAt. AnN. § 14-2-808(a)(i) (LexisNexis 2003).

10. See Del. Code Ann. tit. 13, § 804(a)(4) (1999); Haw. Rev. Stat. Ann. § 584-4(a)(4) (Lexis 1999); Ind. Code AnN. § 31-14-7-2 (Michie 1997); Mass. Gen. Laws Ann. ch. 209C, § 6(a)(4) (West 1998) (requiring the father to cohabitate with the mother, not just the child); MinN. STAT. AnN. $§ 257.55$ Subdiv. 1(d) (West 2003); Mont. Code Ann. § 40-6-105(1)(d) (2003); Nev. Rev. Stat. Ann. $\S 126.051(1)(d)$ (Michie 1998); N.M. Stat. Ann. § 40-11-5A(4) (Michie 1978); N.D. Cent. Code $\S 14-17-04(1)(d)$ (1997); 23 PA. Cons. STAT. ANN. § 5102(b)(2) (West 2001) (creating a presumption of paternity where the father either lived with the child or supported him); Wyo. STAT. ANN. § 14-2-504(v) (LexisNexis 2003) (limiting the presumption to the first two years of the child's life).

11. This is evident by the statutes defining the parent-child relationship in terms of the natural or adoptive parent. See generally Del. Code Ann. tit. 13, § 801 (1999); 750 Ill. Comp. Stat. AnN. 45/2 (Lexis 1999); Minn. Stat. Ann. § 257.52 (West 2003); Mo. Ann. Stat. § 210.817 (West 1996); Mont. Code AnN. § 40-5-234 (2003); N.M. Stat. AnN. § 40-11-4 (Michie 1978); N.D. Cent. Code § 14-17-02 (1997); Wyo. Stat. AnN. § 14-2-308 (LexisNexis 2003).

12. See Del. Code Ann. tit. 13, §§ 805(a), 806 (1999); Haw. Rev. Stat. Ann. $\$ 584-4(a)(6)$ (Lexis 1999); 750 Ill. Comp. Stat. Ann. 45/8(a)(1) (Lexis 1999); Ky. Rev. Stat. AnN. § 213.031 (Michie 1998); Minn. Stat. Ann. § 257.58 (West 2003); Mont. Code Ann. § 40-6-108(3) (2003); Mo. Ann. 
Historically, biological families were given preference in paternity laws ${ }^{13}$ to the exclusion of the non-traditional family because genetics were, and still are, perceived as the catalyst for the desire to perform the parental functions of providing for the economic, social and emotional needs of children. ${ }^{14}$ Biological-identifiable parentage is also the basis of legal ties to the child, including the child's ability to inherit from a parent, receive federal and state benefits, and know his medical history, as well as the parent's ability to obtain visitation, custody or other legal rights associated with parentage. ${ }^{15}$ In addition, because a father is legally obligated to provide financial support for his biological offspring, courts, legislators and society generally believe it is unfair to require a non-biological parent to provide financial support for a child he has not sired or voluntarily undertaken to support. They are concerned that non-biological marital fathers might be less inclined to develop a relationship with their spouse's children for fear of incurring a permanent obligation of child support in the event the marriage fails. ${ }^{16}$

Stat. $\S 210.826 .1,210.826 .2$ (West 1996); Nev. Rev. Stat. Ann. 126.081 (Michie 1998); N.D. Cent. Code § 14-17-06 (1997) (three year limitation); R.I. Gen. Laws § 15-8-6 (2003); Tex. FAM. Code AnN. $\S 160.606$ (Vernon 2002); Wash. Rev. Code Ann. § 26.25.525 (West 1997); L.C. v. T.L., 870 P.2d 374, 378 (Wyo. 1994) (finding in favor of the marital presumption over the hold-out presumption); Paternity of B.J.H., 573 N.W.2d 99 (Minn. Ct. App. 1998) (allowing claim by biological father); Witso v. Overby, 609 N.W.2d 618 (Minn. Ct. App. 2000); Willmon v. Hunter, 761 S.W.2d 924 (Ark. 1988); In re Matter of S.R.H., 981 P.2d 199 (Colo. Ct. App. 1999); see also Theresa Glennon, Somebody's Child: Evaluating the Erosion of the Marital Presumption of Paternity, 102 W. VA. L. Rev. 547, 552, 594 (2000).

13. See Mary R. Anderlik \& Mark A. Rothstein, DNA-Based Identity Testing and the Future of the Family: A Research Agenda, 28 Am. J.L. \& MED. 215, 222 (2002).

14. See id. at 224; Linda D. Elrod \& Robert G. Spector, A Review of the Year in Family Law: Redefining Families, Reforming Custody Jurisdiction, and Refining Support Issues, 34 FAM. L.Q. 607 (2001); Elizabeth S. Scott \& Robert E. Scott, Parents as Fiduciaries, 81 VA. L. Rev. 2401, 2431 (1995) ("Finally, we assume that a substantial motivation leading parents to procreate is the anticipation of rearing their children in a family unit."); see also Marsha Garrison, Law Making for Baby Making: An Interpretive Approach to the Determination of Legal Parentage, 113 HARV. L. REv. 835, 922 (2000).

15. See Jeffrey A. Parness, Designating Male Parents at Birth, 26 U. Mich. J.L. Reform 573, 574 (1993); Paula Roberts, Biology and Beyond: The Case for Passage of the New Uniform Parentage Act, 35 FAM. L.Q. 41 (2001).

16. See G.M.F. v. W.F.F., 728 So. 2d 144, 146 (Ala. Ct. App. 1997); Purvis v. French, 377 So. $2 d$ 674, 677 (Fla. 1979); DeRico v. Wilson, 714 So. 2d 623, 624 (Fla. Dist. Ct. App. 1998); Swain v. Swain, 567 So. 2d 1058, 1059 (Fla. Dist. Ct. App. 1990); K.B. v. D.B., 639 N.E.2d 725, 727-28 (Mass. App. Ct. 1994) (holding that a father has no more of a duty to provide for children born during the marriage resulting from an affair of the wife " "any more than a wife should have a duty to support a child fathered by her husband during their marriage but born of another woman."'); Glennon, supra note 12, at 594 (stating that "[c] ourts hesitate to impose the burdens of parenthood unless presumed fathers voluntarily assumed longlasting parental obligations toward the child. Courts and legislators have long assumed that the sexual relationship that created the biological relationship is an adequate basis for determining a man to be a voluntary father."); see also Hon. Linda L. Chezem \& Sarah L. Nagy, Judicial Abrogation of a Husband's Paternity: Can a Third Party Seek to Establish Paternity Over a Child Born Into a Marriage While that 
Family, like biology, has always been understood as something outside of the child's control. ${ }^{17}$ A child cannot choose his family, from his parents to his siblings, because biology predetermines who his family will be. ${ }^{18}$ As a result, biology "abdicates [parental] responsibility in favor of a predetermined biological self." 19 This leaves the child and family with a non-biological parent open to biological challenges that "have the effect of disrupting or 'disestablishing' families and triggering demands for the elimination of responsibility." 20 This family disruption occurs because, when confronted with a biological truth that excludes a biological relationship with their children, fathers, as well as judges and much of society, often cannot get beyond that fact. ${ }^{21}$ It is as if the existing parent-child relationship dissolves before their eyes and the child becomes a stranger to the parent even though the parent does not become a stranger to the child.

When the legal system encourages or condones the dissolution of the parent-child relationship by failing to acknowledge the families and fathers that exist in society, it creates a construct that cannot meet the needs of the children within those families. It creates a system where children can become legal strangers to the only parents they know and adults' interests prevail over their children's interests. Children should not be disadvantaged because of the choices their parents make, the types of families they are a part of, and their biological connection, or lack thereof, to their fathers. Rather, paternity laws should address families as they exist in society and should be flexible enough to accommodate the changing face of the American family and father by focusing on the child's interests rather than the parents'.

In this Article, I will address the role biology plays in limiting the courts' and legislators' acceptance of non-traditional families in favor of a perceived biological truth that undermines the value of the child's relationships with his caregivers and minimizes the child's interests in favor of the parents. To do so, I will examine the courts' and legislatures' reliance on the marital presumption to define families, as well as the presumption's biological underpinnings.

Marriage Remains Intact?, 30 InD. L. REv. 467, 478 (1997); Roberts, supra note 15, at 54-55.

17. See Janet L. Dolgin, Choice, Tradition, and the New Genetics: The Fragmentation of the Ideology of Family, 32 ConN. L. REv. 523, 544 (2000).

18. $I d$.

19. Id.

20. Anderlik \& Rothstein, supra note 13 , at 225.

21. See Battle Robinson \& Susan Paikin, Who is Daddy? A Case for the Uniform Parentage Act (2000), Del. Law., Summer 2001, at 25, available at Westlaw, 19-SUM Del. Law. 23. 
In Part I, the family, as it is perceived by judges and legislatures, will be contrasted to the family envisioned and needed by children, with an emphasis on the role the father plays in that family. Part II will address how the courts' application of the marital presumption in conjunction with a biological preference further illegitimizes non-traditional families. Part III examines the inherent problems in the traditional family preference, including favoring an adult-centered approach to paternity over a child-centered approach, diminishing the legitimacy of non-traditional families and their children's interest by requiring courts to resort to equitable principles to preserve families, discounting the value of functioning families because of cohabitation and existing marriage preferences and preferring biologically-related strangers to established fathers. Finally, Part IV suggests a child-centered approach to families and paternity decisions that favors the relationships that create families over biology.

\section{Eliminating Non-Traditional Families}

In creating presumptions about paternity, the legislatures and courts indirectly define what constitutes a family. When the definition of a family is limited by the father's biological ties to the children, children with parents, male or female, that are not biologically related to them, lose parental and family ties and the legal, social and economic benefits that accompany those roles. Because children often do not share the courts' and legislatures' vision of what a family should be, defining a family by biology is counterproductive to the needs of the child.

For example, if a child were conceived out-of-wedlock and the mother left the child with the biological father and his girlfriend for five years, the girlfriend, because she is a non-biological mother, would have no rights to the child unless she married the child's biological father and became the child's stepmother. Even then, her rights would be subordinate to the biological mother's rights in the event of the biological father's death, as well as to the biological father and mother in the event of a divorce. While the unmarried couple could maintain a family centered around the child, the biological mother could legally step into the family at any time as though she never left. From the child's perspective, the law has now destroyed his family and forced a relationship with a perfect stranger.

Biology, however, has always been the basis of determining parentage and familial relationships. It started with presumed biological ties under the marital presumption and continues to exist through genetic testing. Even most hold-out provisions are tied to biology because they provide for parentage 
when the child lives with a non-biological parent who holds the child out as his biological child.

Many families, however, exist without biological ties even after the biological truth is discovered. Those families exist as a result of the relationship with the children, not the biological bonds that hold a perceived preference under paternity laws. While those families exist even in the absence of legal protections, without legal recognition, they are vulnerable to biological attacks, making them less stable for the children who rely on them. Therefore, non-traditional families require recognition and acceptance under parentage laws.

\section{A. Family Defined}

In the example given above, where the mother left for five years only to return to a family that developed without her, had the father been a biological stranger to the child, the biological mother could legally exclude both him and the girlfriend from the child's life. In that scenario, the child would lose his entire family under a system favoring biology over relationships. This is an example of what can happen when biology underlies definitions of families to the exclusion of all else, as in the marital or legitimacy presumption.

In addition, when the Uniform Parentage Act was redrafted to limit the hold-out provision to those fathers who lived with the child for the first two years of the child's life, the new law narrowed the definition of legallyprotected non-traditional families, and realigned the law even closer to a biologically-based system.

\section{The Marital Presumption as a Biological Norm for Traditional Families}

The marital or legitimacy presumption evolved from the sixteenth century out of English common law..$^{22}$ Based on the biological assumption of pater est quem nuptiae demonstrant ${ }^{23}$ or "marriage establishes who the father is," the

22. See Jill Handley Anderson, The Functioning Father: A Unified Approach to Paternity Determinations, 30 J. FAM. L. 847 (1992); Dolgin, supra note 17, at 527; Glennon, supra note 12, at 562; Brie S. Rogers, The Presumption of Paternity in Child Support Cases: A Triumph of Law Over Biology, 70 U. CIN. L. Rev. 1151, 1152 (2002); Roberts, supra note 15, at 44 (2001).

23. Edward R. Armstrong, Note, Family Law-Putative Fathers and the Presumption of Legitimacy-Adams and the Forbidden Fruit: Clashes Between the Presumption of Legitimacy and the Rights of Putative Fathers in Arkansas, 25 U. Ark. Little Rock L. Rev. 369, 371 (2003). 
marital presumption exists in virtually every state as adopted from the Uniform Parentage Act of 1973 or some variation thereof. ${ }^{24}$

In the sixteenth century, the marital presumption sought to create certainty in paternity. It did so by establishing biological certainty on the basis that children conceived during the period of the marriage would logically be the biological offspring of the marriage because to presume otherwise would mean that the wife had committed an act of infidelity. ${ }^{25}$ In a sense, this protected women, children and families because it preserved intact family relationships. ${ }^{26}$ It was also intended to establish biological certainty when medical science could not. ${ }^{27}$

The marital presumption was also believed to protect families by promoting a peaceful union between the mother and father, which would ultimately benefit the family. ${ }^{28}$ It would do so by avoiding disputes between the parents about the child's paternity, which was believed to result in stability and harmony within the family, as well as freedom from paternity disputes in the courts. ${ }^{29}$

The marital presumption also protected children at a time when fathers had complete control over their economic and social well-being. ${ }^{30}$ Applying the marital presumption, legitimate children born of a marriage were generally not at risk of becoming illegitimate and losing their inheritance, property rights, economic support or their father-child relationship. ${ }^{31}$ As time passed, the marital presumption furthered additional policies believed to benefit marital children, including eligibility for health insurance and governmental

24. See Diane S. Kaplan, Why Truth is Not a Defense in Paternity Actions, 10 Tex. J. Women \& L. 69, 70 (2000); see also Unif. Parentage Act § 204 (2000).

25. See Dolgin, supra note 17, at 534 .

26. See David V. Hadek, Why the Policy Behind the Irrebuttable Presumption of Paternity Will Never Die, 26 Sw. U. L. Rev. 359, 360 (1997); Kaplan, supra note 24, at 71; Roberts, supra note 15, at 53; see also Traci Dallas, Rebutting the Marital Presumption: A Developed Relationship Test, 88 Colum. L. REv. 369, 372 (1988).

27. "The presumption permitted courts to assume a set of biological facts (and thus a history of relationships) in order to safeguard a traditional model of family." Dolgin, supra note 17, at 528.

28. See Chezem \& Nagy, supra note 16, at 468; Dallas, supra note 26, at 372; Hadek, supra note 26, at 360; Kaplan, supra note 24, at 71; Roberts, supra note 15, at 53.

29. Kaplan, supra note 24 , at 71 . The marital presumption was also created to benefit the "public fisc" in that children would not become illegitimate and wards of the state or church if the husband was also deemed to be the child's biological father. Roberts, supra note 15, at 54 .

30. See Hadek, supra note 26, at 360 .

31. See Armstrong, supra note 23, at 372; Hadek, supra note 26, at 360; Rogers, supra note 22, at $1151-52$. 
benefits such as social security disability and survivor's rights, as well as knowledge or access to medical history and cultural heritage. ${ }^{32}$

The biological underpinnings that created the marital presumption were, however, eventually used to rebut it. For instance, while a husband and wife were originally prohibited from testifying against the other ${ }^{33}$ in a paternity action in order to preserve the biological assumption of the marital presumption, the law soon allowed the husband to establish non-paternity on the basis of perceived biological certainties such as proof that the husband was impotent, sterile, or could not procreate because of his age. ${ }^{34}$ The husband could also show that he lacked access to his wife during the periods of conception and gestation because he was imprisoned or was beyond the four seas of England. ${ }^{35}$ He could even speculate about his wife's infidelity as an adulterer if she left him to live with another man. ${ }^{36}$

By the end of the nineteenth century, biological assumptions, conjecture and pseudo-accuracy gave way to biological certainty when DNA test results became a generally-accepted truth that could be used by the father, mother, or other interested party to rebut the marital presumption or establish paternity in children born out of wedlock. ${ }^{37}$ Since the marital presumption depends on biological assumptions for its foundation, the additional use of biological absolutes through genetic testing is consistent with the marital presumption even though the biological truth can, by contradicting the underlying biological assumption of the marital presumption, result in the opposite outcome of the marital presumption.

When certainty is created through genetic test results, which may show that someone outside the marriage is a biological parent, the policies behind the marital presumption are undermined. Instead of fostering and preserving family relationships between the parents, the existence of a perceived biological truth encourages fathers to doubt their wives' fidelity, accuse them

32. See Chezem \& Nagy, supra note 16 , at 468 ; Hadek, supra note 26 , at 360 ; Roberts, supra note 15 , at $53-54$.

33. Anderlik \& Rothstein, supra note 13, at 223; Anderson, supra note 22, at 852; Glennon, supra note 12, at 564; Kaplan, supra note 24, at 70; Lynne Marie Kohm, Marriage and the Intact Family: The Significance of Michael H. v. Gerald D., 22 WhitTIER L. Rev. 327, 335 (2000); Rogers, supra note 22, at 1153-54.

34. Kaplan, supra note 24, at 70; Rogers, supra note 22, at 1153-54; see also Dolgin, supra note 17 , at 527; Glennon, supra note 12, at 565; Roberts, supra note 15, at 44.

35. Armstrong, supra note 23, at 372; see also Bartlett, infra note 41, at 920; Dolgin, supra note 17 , at 527; Glennon, supra note 12, at 565; Kaplan, supra note 24, at 70; Roberts, supra note 15, at 44; Rogers, supra note 22, at 1153-54.

36. Roberts, supra note 15 , at 44 .

37. See infra notes $158-75$ and accompanying text. 
of fraud and misrepresentation, and end the marital, as well as parental relationships. As a result, where the marital presumption was meant to preserve intact families, believing the family, especially the children, benefitted from its continued existence, a biological truth tears families apart, often leaving the child with a broken family and without the father-child relationship the child has come to rely upon in the existing family.

While arguably the marital relationship may no longer be intact by the time the paternity challenge comes to court, ${ }^{38}$ the family can continue because the child's family does not end when the marriage does. The child still has two parents and possibly siblings. The living arrangements may change, but parent-child relationships can, and often do, remain intact. ${ }^{39}$ The family, however, ends with the marriage when the father is blinded by biology. He ends an existing, often long-term, relationship with his child because of a biological truth that has nothing to do with the father-child relationship. ${ }^{40}$

Even though parentage and paternity laws recognize the biologicallybased family, the child only understands the relationships that make up his family, not the genetics. While those relationships can lose their importance under parentage laws when they are not founded in biology, they are not so easily disposed of by the child whose emotional, financial and psychological well-being grew out of those relationships. ${ }^{41}$

Furthermore, the policy of preserving the child's best interests is not served when biology causes the child's father to abandon him. The child is undoubtedly harmed by the loss of a parent, regardless of the lack of a biological relationship with the parent. The "fathers," both biological and non-biological, are the ones who decide whether to establish, maintain or end the parent-child relationship under the marital presumption, allowing an existing parent to decide whether to continue the relationship with the child without considering the child's interests in preserving his existing family.

38. See State v. Thomas, 584 N.W.2d 421, 425 (Minn. Ct. App. 1998); Sandra S. v. Larry W., 667 N.Y.S.2d 632, 633 (N.Y. Fam. Ct. 1997); Garst v. Hopkins, No. 2002-CA-S0, 2003 WL 1571704, at*3 (Ohio Ct. App. Mar. 28, 2003) (relying on the lack of a family where the parents lived apart within a few months of the child's birth, along with the mother's remarriage, to deny the father's argument that he failed to challenge paternity because he was trying to preserve a relationship with the child's mother).

39. See infra notes 57-84 and accompanying text.

40. See Glennon, supra note 12, at 566. "In some in stances, child support enforcement undermines the fragile father-child relationship that does exist, turning the parents into adversaries." Id. at 558-59.

41. See Katherine T. Bartlett, Rethinking Parenthood as an Exclusive Status: The Need for Legal Alternatives When the Premise of a Nuclear Family Has Failed, 70 VA. L. REV. 879, 903 (1984). But see Cain v. Cain, 777 S.W.2d 238, 239 (Ky. Ct. App. 1989) (discussing that after the eleven-year-old child's mother told him that her former husband was not his biological father, both father and child suffered problems until the child refused to see the father and the father eventually challenged paternity). 
The piece of paper issued by the county clerk and signed by either a religious or public servant should not validate or underlie preserving the marital presumption, but the relationship between the parent and child, the same relationship that exists without marriage, without cohabitation, and sometimes without even the same last name, should be the determining factor.

\section{Children Born Out-of-Wedlock Left Family-less}

Most states have adopted provisions in their paternity statutes similar to those in the Uniform Parentage Act, proclaiming children born to unmarried parents to have the same legal rights as those born to parents that are married to each other. ${ }^{42}$ "From a legal and social policy perspective, this is one of the most significant substantive provisions of the Act, reaffirming the principle that regardless of the marital status of the parents, children and parents have equal rights with respect to each other." ${ }^{43}$

The rights afforded to children with two biological parents are, however, more encompassing than those afforded to children with fathers who are not biologically related to them. While the Uniform Parentage Act acknowledges a generic disparity in treatment between marital and non-marital children in the context of other statutes ${ }^{44}$ it fails to acknowledge the disparities within the Act regarding children of non-biological parents who are neither adopted nor products of other artificial insemination procedures.

The failure to give equal protection to children of non-traditional families is founded in the treatment of children born out-of-wedlock. Unlike Hester Prynne, who was forced to live out her days wearing a scarlet letter, ${ }^{45}$ historically, the problem of illegitimate children was resolved with a parentcentered approach - the parents, or, at least the mother, was stoned to death as an adulteress. "Under such a public policy, there was never the legal need to establish paternity."

42. See Del. Code Ann. tit. 13, § 802 (1999); Haw. Rev. Stat. Ann. § 584-2 (Lexis 1999); Minn. Stat. Ann. § 257.53 (West 2003); Mo. Ann. Stat. § 210.818(West 1996); Mont. Code Ann. § 40-5-103 (2003); Nev. Rev. Stat. Ann. 126.031 (Michie 1998); N.M. Stat. Ann. § 40-11-3 (Michie 1978); 23 Pa. Cons. Stat. Ann. § 5102(a) (West 2001); Tex. Fam. Code Ann. § 160.202 (Vernon 2002); Wash. Rev. Code Ann. $§ 26.26 .020$ (West 1997); Unif. Parentage Act $\S 202$ (2000), 9B U.L.A. 309 (2001).

43. Unif. Parentage Act $\S 202 \mathrm{cmt}$. (2000), 9B U.L.A. 310 (2001).

44. Id.

45. See Nathaniel Hawthorne, The Scarlet Letter (1850).

46. See E. Donald Shapiro et al., The DNA Paternity Test: Legislating the Future Paternity Action, 7 J.L. \& Health 1, 9 (1993).

47. $I d$. 
Roman law handled the issue in much the same manner, burying the "Vestal Virgin" alive. ${ }^{48}$ When a child was born of an unmarried woman, it was labeled "filius nullius," the child of no one. ${ }^{49}$ As a result, the child lacked any right to demand that his father support him and could not claim a right to inherit. ${ }^{50}$ Eventually, paternity laws changed so that the child of no one could maintain an action to establish parentage in someone - his biological father. ${ }^{51}$ However, the purpose for allowing the child to establish parentage in his biological father was not to provide for the child's "emotional, psychological, or familial good ... ; it was brought to relieve the public from the burden of the child's support." 52

Children born out-of-wedlock used to be a small fraction of all children born, with a low of $8 \%$ of all births in 1965 ; however, the number of children born out-of-wedlock was recently calculated at almost a third of all births in the United States alone. ${ }^{53}$ Today, a child may be declared to be born out-ofwedlock when he is either born to an unmarried couple or he may later be declared to be born out-of-wedlock when a paternity challenge is made in one of three circumstances, including: 1) when a biological father seeks to establish paternity of a child born to a married couple; 2) when a nonbiological father attempts to disestablish paternity when the marriage ends or at a later time; or 3) when a biological mother wants to end the parental relationship of the non-biological marital father at the time of divorce or later. $^{54}$ However, the marital presumption offers a perceived protection to those children, at least as long as the marriage is intact. ${ }^{55}$

When there is an existing family, whether through marriage or otherwise, parentage laws fail to provide children with a means of facilitating parent-

48. Id.

49. Id. at 10; Glennon, supra note 12 , at 553 .

50. See Shapiro et al., supra note 46 , at 10.

51. See statutes cited supra note 5.

52. Roberts, supra note 15 , at 45 . "The child support system for children born out of wedlock is based on the assumption that biological fatherhood is a sufficient basis for legal and financial responsibility for a child. ... It is irrelevant whether there is a social parent-child relationship between the child and the parent." Glennon, supra note 12, at 558.

53. See Irwin Garfunkel et al., The Roles of Child Support Enforcement and Welfare in Non-marital Childbearing, J. Population Econ. 55, 56 (2003); Garrison, supra note 14, at 887.

54. See infra Parts IIA-B, III B, D, and cases discussed therein.

55. See Armstrong, supra note 23, at 372; Chezem \& Nagy, supra note 16, at 468; Dallas, supra note 26, at 372; Dolgin, supra note 17, at 528, 534; Hadek, supra note 26, at 360; Kaplan, supra note 24, at 71; Roberts, supra note 15, at 53; Rogers, supra note 22, at 1151-52. "[O]ne report suggests that as many as ten percent of all children born to married women in the 1940s were quasi-marital children." Chris W. Altenbernd, Quasi-Marital Children: The Common Law's Failure in Privette and Daniel Calls for Statutory Reform, 26 FLA. ST. U. L. REV. 219, 227-28 (1999). 
child relationships with their non-biological parents, whereas the biological parent can force a legally-sanctioned relationship with the child by requesting visitation and even custody of the child. The biological father's right exists in some cases even if the mother subsequently marries a man who takes on the parental responsibilities for the child. ${ }^{56}$ Yet, children born out-of-wedlock only seeking financial support from their biological fathers are more likely to succeed than those seeking emotional, financial or psychological support from a non-biological father because paternity laws primarily protect relationships based on either biology or a biological-premised marital presumption, rather than on the emotional, social and psychological relationship between the parent and child.

\section{Modern Families: Beyond Tradition}

The United States Supreme Court's preference for marital families ${ }^{57}$ is not without merit. The benefits of a stable, functioning two-parent family where both adults are biologically related to the child are undisputed..$^{58}$ Limiting legal protection to children of traditional families, however, is inconsistent with the child's and non-traditional family's interests. It assumes that children in non-traditional families suffer undue financial, emotional and social problems that could be remedied by the stroke of the pen to a marriage license. This is an unsound premise because societal, economic and emotional problems arise not out of the form of the family, but rather as a result of a missing component to the family-a father. ${ }^{59}$

It is when the father, regardless of whether his prior relationship with the mother was consummated in marriage, cohabitation, or a one-night stand, is missing from the child's life that the child suffers economic and emotional problems. ${ }^{60}$ The child also suffers if the mother goes missing from the child's life. Either parent's absence from a child's life is especially harmful if there was an existing parent-child relationship with the now-absent parent. ${ }^{61}$

56. See Witso v. Overby, 609 N.W.2d 618, 622 (Minn. Ct. App. 2000), aff'd 627 N.W.2d 63 (Minn. 2001), cert. denied, 534 U.S. 1130 (2002).

57. See Michael H. v. Gerald D., 491 U.S. 110 (1989) (finding for a man who was not the child's biological father, but was married to the mother); see also L.C. v. T.L., 870 P.2d 374, 380 (Wyo. 1994).

58. See Armstrong, supra note 23, at 372; Chezem \& Nagy, supra note 16, at 468; Hadek, supra note 26, at 360; Roberts, supra note 15, at 53-54.

59. See Barbara Bennett Woodhouse, Hatching the Egg: A Child-Centered Perspectiveon Parents' Rights, 14 CARDozo L. Rev. 1747, 1761-62 (1993).

60. Id. at 1762-63.

61. See Bartlett, supra note 41, at 909-10. 
Acknowledging that children suffer from the loss of any part of a family, limiting the form of the family will not eliminate the potential for that harm as traditional families are as likely to end as non-traditional ones.

Since parentage laws limit the form of legally-recognized families, nontraditional families that are not similar in form to marital families or that are not based in biology are left without legal protections afforded to absentee biological fathers who decide to take a role in their children's lives when convenient. Parentage laws assume that biology ${ }^{62}$ or marriage ${ }^{63}$ predicates the motivation for parenting, and, therefore, the basis for defining a family entitled to legal protection. ${ }^{64}$ This belies the current form of many American families, which include both biological and non-biological parents.

In contrast to the ideal of a traditional family, which is presumed to be based on biological relationships between the parents and child or a marital relationship between the parents, ${ }^{65}$ many families no longer resemble the traditional marital family. "Yet, it is widely hoped, if not expected, that once formed, these families will resemble one another in placing love and loyalty before all else." ${ }^{97}$ Families, like people, come in all shapes and sizes and function not based on their form but on their relationships. ${ }^{68}$

The family relationship develops from the conduct of the parents in providing for the care, support and growth of the children in the family. ${ }^{69}$ While that relationship can arise as a result of marriage, adoption, or a surrogacy agreement, ${ }^{70}$ it can also occur from "behavioral factors such as emotional attachments and daily association." ${ }^{.71}$ Nor are families stagnant

62. See Bartlett, supra note 41, at 920 . "According to the parental rights doctrine, this biological link between parent and child stimulates responsible parenting and thus is a key ingredient in establishing an adult's parental rights. Nonetheless, when unwed parents do not offer their children a family whose adult members are legally committed to one another, the family that the doctrine of parental rights seeks to promote simply does not exist." Id. at 919.

63. See Leslie Joan Harris, Reconsidering the Criteria for Legal Fatherhood, 1996 UtAH L. Rev. 461, 463 (1996).

64. See Anderlik \& Rothstein, supra note 13, at 222; Harris, supra note 63, at 461.

65. See Bartlett, supra note 41, at 881; Dallas, supra note 26, at 372.

66. Woodhouse, supra note 59, at 1762. "Children in single-parent homes have become the fastest growing segment of Americans living in poverty. Children today are more likely than ever before to grow up without either the material or emotional support of a father." Id.

67. Dolgin, supra note 17, at 525 .

68. Id.; see also Woodhouse, supra note 59, at 1761.

69. See Dallas, supra note 26, at 372 .

70. See Gary B. Melton, The Significance of Law in the Everyday Lives of Children and Families, 22 GA. L. Rev. 851, 883-84 (1988) (citing Shaver v. Hunter, 626 S.W.2d 574, 579 (Tex. Ct. App. 1981) (Countiss, J., concurring).

71. Dallas, supra note 26 , at 372 . 
beings. They are "organisms. The love of one parent for the other nourishes the child and creates a friendly environment for growth." ${ }^{.2}$ Rather than being formed by an event such as marriage, the child's birth, or living together, families evolve over time and become families as the parent-child relationships grow.

Therefore, while a marriage can create a family, a family does not start or end with the parents' marital relationship. Nor does it succeed or fail based on the living arrangements of the parents. Rather, it is grounded in the relationships between the parents and the child and the function of the parents and children as a family, regardless of its form.

The marital presumption is often favored as involving a more stable relationship than a non-marital relationship. ${ }^{73}$ Yet marriage does not guarantee a functioning family relationship, nor does it ensure that the parents will remain in the same home as the child. Because almost half of marriages in America end in divorce, the assumption that marriage creates certainty where other familial relationships do not is no longer supportable. ${ }^{74}$

Likewise, there is no merit to the argument that families end in divorce, leaving no policy other than the child's legitimacy to protect. ${ }^{75}$ Holding that divorce ends families assumes that the family only remains intact during the course of the marriage and that the parental relationship to the child is dependent on the existence of a current intimate relationship between the parents. If families ended in divorce, the marital dissolution would leave children fatherless, illegitimate, and without the financial and emotional support a father can provide a child, regardless of his feelings about the child's mother. While some fathers inevitably play less of a daily role in the care of their children when they leave the family home, ${ }^{76}$ others maintain familial relationships with their children after divorce, sharing custody, picking the children up from school, working on homework with them or coaching their athletic teams. Therefore, when family is tied to marriage, the goal of a functioning family only has a $50 \%$ chance of success; a bet most gamblers would not even consider taking, let alone risking emotional, financial and social resources.

72. Woodhouse, supra note 59, at 1761.

73. See Mary Kay Kisthardt, Of Fatherhood, Families and Fantasy: The Legacy of Michael H. v. Gerald D., 65 Tul. L. Rev. 585, 587 (1991); see also SARA L. McLAnahan, Life Without FAther: What HapPens to the Children? (Ctr. for Research on Child Wellbeing, Working Paper No. 01-21, 2001).

74. See Kisthardt, supra note 73, at 627 n.290.

75. See Rogers, supra note 22, at 1152.

76. See McLanahan, supra note 73; Scott \& Scott, supra note 14, at 2443. 
An alternative to marriage, cohabitation is sometimes protected by parentage laws. ${ }^{77}$ Arguably, cohabitation gains credibility as a practical alternative to marriage because it can function similarly to a traditional family in that two parents presumably biologically related to the child live in the same house and raise the child together. ${ }^{78}$ "[C]ohabitation should be treated as an alternative to marriage, because many people reject marriage but find the same positive values associated with marriage in cohabitation arrangements." 79

A family is not dependant on the living arrangements of the parents and the child. In contrast, some psychoanalytic theorists propose that children need a stable parental relationship with one parent to the exclusion of the other parent. ${ }^{80}$ The exclusion of the non-custodial parent is exactly the type of scenario that could result if hold-out provisions are eroded, as in the 2002 Uniform Parentage Act, or eliminated altogether, as in some states. ${ }^{81}$ This solution would disrupt those families where the children have always had a dual-parent relationship where one parent never lived with them or only lived with them on a part-time basis.

A sweeping rule excluding parents who live outside the child's residence from the child's family would create an unnatural parental environment for those children where the parents living apart is the norm, and would end familial and parental relationships when the parents divorce and one parent has primary physical custody of the child. It would also prohibit alternative custody arrangements where children split their time living with each of the parents. Under an exclusive parenting theory, since parental obligations of child support are not tied to visitation or custody rights, the excluded parent would presumably have an obligation to support his child but would be prohibited from taking a part in his life, ending the family and parent-child relationship.

Although non-traditional families require the courts to make case-by-case determinations of parentage without the bright line biological truth supporting parentage ${ }^{82}$ ignoring those families will not force them to pursue a traditional

77. See Laurence C. Nolan, Legal Strangers and the Duty of Support: Beyond the Biological Tie-But How Far Beyond the Marital Tie?, 41 Santa Clara L. Rev. 1, 33 (2000).

78. Id.

79. $I d$.

80. See Jon Elster, Solomonic Judgments: Against the Best Interest of the Child, 54 U. CHI. L. REv. 1, 4 (1987).

81. See infra note 120 and accompanying text.

82. See Harris, supra note 63, at 473. 
marital-family relationship when they otherwise would not do so. ${ }^{83}$ Because families exist with two parents who never marry, never live together and are not biologically related to their children, they are not limited by biology—even if the law is. ${ }^{84}$

\section{Modern Fathers: A New Tradition for Families}

Assume a man dates a woman and she becomes pregnant. While they decide that they are not ready for marriage, they want to co-parent the child, forming a non-traditional family where the father and child live apart. Even though the child's father cares for the child on a regular basis, provides financial support for the child, and develops a father-child relationship with the child built on mutual love and caring, the family is afforded no protection under the law without a genetic test adjudicating the father as a biological parent to the child or marriage between the child's parents providing protections afforded under the marital presumption. The hold-out provisions in most parentage laws would provide the child with no legally-recognized family or parental relationship since his father never lived with him.

If the child's mother later wishes to exclude the father from the child's life, she can do so at her whim and require him to come forward and prove biological parentage - the existence of a genetic relationship between the father and the child. If such a genetic relationship exists, the father will be obligated to financially support the child and may, if the court deems it to be in the best interests of the child, be entitled to visitation and possibly custody of the child. Assuming the genetic tests disprove a biological connection between the father and the child, the child's mother can terminate the parental relationship with the father at her will. Neither the child nor the father has any legally protected interest in the relationship, no matter how beneficial it is for the child.

The need to identify the child's father as a means of defining the family is not unique. Since the days of Carthage to the present day, the tribunals, councilmen and courts have attempted to determine a child's biological parentage by his resemblance to his father, blood type, blood groupings, and now, DNA. ${ }^{85}$ With DNA evidence creating a biological truth that sometimes

83. About a third of all children born in the United States are not born into a traditional family unit. See Garrison, supra note 14, at 887; Woodhouse, supra note 59, at 1762; see also Kisthardt, supra note 73 , at 641 .

84. See Melton, supra note 70 , at 878 .

85. For a comprehensive overview of the history of "bald eagle" and paternity law, see Shapiro et 
conflicts with the existing family, the perceived certainty DNA was supposed to provide ends up turning into uncertainty about how fathers and families are defined. ${ }^{86}$

Current law sends the message that genetic contribution to the creation of a child through sexual intercourse, without any other kind of connection to the child or mother, is a sufficient basis for legal fatherhood, with the attendant duty to provide financial support to the child up to the age of eighteen, and possibly beyond. ${ }^{87}$

The argument that a father is identified by his genes and a family is defined by the father's relationship to the child's mother ${ }^{88}$ assumes that families are created based on adult relationships with each other rather than with the child. ${ }^{89}$ Approaching fatherhood and families from a child-centered approach, fathers can be identified by their relationship with the child and a family can be defined by the relationships of each parent with the child..$^{90}$

Identifying a father by his relationship with the child does not require that the father have a biological connection with the child. ${ }^{11}$ Nor does defining a family by the parents' relationships with the child require marriage or cohabitation. The family, like the father-child relationship, is created by the parents' love for their children and the family grows from the "companionship, interplay, and mutuality, fulfill[ing] the child's psychological . . a as well as physical needs." ${ }^{, 92}$ Under a relationship standard, the father is identified and the family remains intact, despite the lack of an intimate adult relationship between the parents. ${ }^{93}$

al., supra note 46, at 16 (citing Douglas Peerage Case, 2 Hargrave, Collectanea Juridica 402 (1769)).

86. For example, Joseph of Nazareth married Mary knowing the child was not his biological child and raised him anyway. Woodhouse, supra note 59, at 1773. Jesus is generally deemed the Son of God, minimizing Joseph's role.

87. Anderlik \& Rothstein, supra note 13, at 218; see also Harris, supra note 63, at 474.

88. See Michael H. v. Gerald D., 491 U.S. 110 (1989); see also Harris, supra note 63, at 463.

89. See Woodhouse, supra note 59, at 1761.

90. The concept of a parental relationship with the child has been described by scholars and courts as a functional relationship, developed relationship, social relationship, psychological relationship or parenting relationship. See generally Anderson, supra note 22; Dallas, supra note 26; Rogers, supra note 22 , at 1157 .

91. See Marsha Garrison, Why Terminate Parental Rights?, 35 Stan. L. Rev. 423, 447 (1983). 1981)).

92. See id. (quoting J. Goldstein et Al., Beyond the Best Interests of the Child 98 ( $2 \mathrm{~d}$ ed.

93. See id. at 464 (citing J. Wallerstein \& J. Kelly, Surviving the Breakup: Children and Parents Cope with Divorce 219 (1980)). Even a bad relationship with the non-custodial parent is preferred to complete abandonment. Id. at 464-65. 
Although the family's geography changes when parents divorce, as one party leaves the family home or the parents end their relationship, ${ }^{94}$ the father and the family do not have to lose their roles in the child's life. To the contrary, the father is still identifiable by his relationship with the child, the time he spends with the child through visitation, joint custody or other contact with the child. It also exists by the father's role in providing financial support for the child. The family is also defined by the relationships the child holds with each parent because the family does not depend on parental geography to maintain its form or function.

Furthermore, geography affects families every day without displacing fathers or destroying families. When children turn eighteen, they go to college, get jobs, find their own homes and often leave the city or state where their parents reside. When the child leaves the family home, no one contends that the child no longer has a father or that the family no longer functions. It is an expected part of the evolution of families, the roles of the members of the family, and the ultimate formation of extended families.

The same thing happens with divorce or the end of any adult-adult relationship involving children. While the family evolves and the day-to-day dynamics of the family changes, the child does not lose his father or family because his parents have decided to end or change their relationship. The reason the family and father-child relationships survive the sometimes dramatic ends to parental relationships is because the child's relationship with his parents does not turn on the family's geography or daily activities. ${ }^{95}$

Because relationships with the child are what identify fathers and define families, approaches to parentage that label a child's father and family at the time of birth ${ }^{96}$ are misguided and counterproductive to a child's well-being. Such approaches ignore the meaning of parentage, which is an adult who takes on the obligation of supporting, caring for and loving the child. Meanwhile, a biological parent may have no more of a relationship with the child than to have provided the sperm necessary for conception. Preferring the sperm donor over the functioning father fails to consider the child's familial attachments.

94. See Roberts, supra note 15, at 56; Rogers, supra note 22, at 1172.

95. Scott \& Scott, supra note 14 , at 2402 .

96. See Parness, supra note 15, at 575. 


\section{B. Reinforcing Traditional Families By Limiting Hold-Out Laws}

While hold-out provisions, which presumably base paternity on a father's actions, have the feel of protecting father-child relationships, and, therefore, non-traditional families, the limitations in the provisions favor biology over the parental relationship they proclaim to protect. By limiting families to those situations where the father lived with the child for the first two years of the child's life and held the child out as his "natural" (aka biological) child, the 2002 Uniform Parentage Act's amended provision perpetuates a biological fiction that the father who lives with a child during the child's infancy is more likely to be the biological father as he is motivated to care for the child based on the desire to promote the survival of his genes. ${ }^{97}$ Likewise, because sociologists believe there is a link between biology and the parent's desire to care for the child ${ }^{98}$ the first two years provision in the 2002 Uniform Parentage Act is consistent with a biological preference.

The limitation of hold-out provisions to the first two years of the child's life also belies the policy of obtaining permanent parents for the child because it requires cohabitation with the child's mother, a situation which may not be emotionally beneficial to any of the family members, as well as the assumption of parental status during the child's early years, creating the possibility that a long-term parent-child relationship will be found to be invalid based on the time the father began the relationship with the child.

For example, if a child's biological father dies when he is six months old and another man becomes the child's father by caring for the child and developing a parent-child relationship with the child but does so without living with the child until after he is two or begins the relationship with the child once the child has already turned two, the family or father-child relationship is not protected under the hold-out provision. Six years later, the mother or the non-biological father can end the family and parental relationship without legal ramification or concern for the emotional or financial needs or interests of the child.

Although broader hold-out provisions create a presumption of paternity when the father holds the child out as his own — his biological child — at any time during the child's minority, ${ }^{99}$ these provisions still fail to protect many

97. See Anderlik \& Rothstein, supra note 13, at 224; Scott \& Scott, supra note 14, at 2434.

98. See Bartlett, supra note 41, at 889 (citing J. Locke, The Second Treatise of Civil Government 85 (J.W. Gough ed., 1947) (1690)); Woodhouse, supra note 59, at 1858.

99. See Del. Code Ann. tit. 13, § 804(a)(4) (1999); Haw. Rev. Stat. Ann. § 584-4(a)(4) (Lexis 
non-traditional families where the fathers do not live with the child because cohabitation is almost always a requirement to establish parentage under the hold-out provisions. When the father does not live with the child, or at least not within the period proscribed by the statute, then the child has no familial or paternity rights in the father, regardless of the length of time the parentchild relationship exists. ${ }^{100}$ If the current hold-out provisions of the Uniform Parentage $\mathrm{Act}^{101}$ are adopted by a third of the states in the next twenty years, following suit with the 1973 version of the Act, the biological connection between families and paternity will become even stronger. In limiting protection for non-traditional families to those that involve an adult-adult relationship with the child's mother, many similar parentage laws rely on the family's form over its function.

The exception is codified in the 2002 Uniform Parentage Act's estoppel section, ${ }^{102}$ which permits courts to deny genetic testing necessary to rebut presumptive fatherhood when a father-child relationship can be established, as well as in the Pennsylvania and Alabama hold-out provisions, ${ }^{103}$ which create a presumption of paternity without requiring the father to live with the child. Under these provisions, the child whose biological father died when he was six months old can rely on his familial and father-child relationship with the father who raises him because the law protects that relationship.

\section{Holding Out a Biological Connection}

Uniform paternity laws have existed in some form or another since 1922 when the Uniform Illegitimacy Act was first addressed by the National Conference of Commissioners on Uniform State Laws (NCCUSL). ${ }^{104}$ While other uniform acts addressing paternity, illegitimacy and blood tests were also considered in subsequent years, the next major development in national paternity legislation, the Uniform Parentage Act, an act that encompassed

1999); Ind. Code Ann. § 31-14-7-2 (Michie 1997); Mass. Gen. Laws Ann. ch. 209C, § 6(a)(4) (West 1998 ) (requiring the father to cohabitate with the mother, not just the child); MinN. STAT. AnN. $§ 257.55$ Subdiv. 1(d) (West 2001); Mont. Code Ann. § 40-6-105(1)(d) (2003); Nev. Rev. Stat. Ann. 126.051(1)(d) (Michie 1998); N.M. Stat. Ann. § 40-11-5(A)(4) (Michie 1978); N.D. Cent. Code $\S 14-17-04(1)(d)$ (1997).

100. See supra note 58.

101. Unif. Parentage Act $\S 204(a)(5)$ (2000), 9B U.L.A. 14 (Supp. 2003).

102. See id. $\S \S 607,608$ (2000), 9B U.L.A. 25-27 (Supp. 2003).

103. Ala. Code $§ 26-17-5(a)(4)(1992)$; Pa. Cons. Stat. AnN. $\$ 5102(b)(2)$ (West 2001).

104. Unif. Parentage Act, 2000 Prefatory Note, 9B U.L.A. 4 (Supp. 2003). 
parentage for children born in- and out-of-wedlock, followed in $1973 .{ }^{105}$ In the twenty-seven years that followed, it was adopted in full by nineteen states while other states enacted considerable portions of the act in their paternity laws. ${ }^{106}$

The NCCUSL began revising the Uniform Parentage Act in 1997 to address policy concerns where biology and the law conflicted. ${ }^{107}$ The Uniform Parentage Act was revised in 2000 to accommodate changes in medical technology and inconsistencies in common law decisions under the 1973 version of the Act. ${ }^{108}$ The drafters also incorporated uniform acts dealing with assisted reproduction, custody, support, and putative father registries within the 2000 amendments to the Uniform Parentage Act as recently amended in 2002. ${ }^{109}$

Staple provisions of the 1973 Act remain in the 2002 Uniform Parentage Act, including the marital or legitimacy presumption. ${ }^{110}$ However, while the original version of the Act presumed paternity as long as the father resided in the same home as the child and held out the child as his own, ${ }^{111}$ the new provisions limit the presumption to the first two years of the child's lifetime when a father is not biologically related to the child but takes the child into his home and holds the child out to the general public as his own. ${ }^{112}$

The 2002 Uniform Parentage Act drafters acknowledged the significance of the amendment, but justified the limitation as a solution to uncertainties that arose under the old Act regarding whether the presumption would occur even if the child only lived with the father for a short period of time or lived with the father "long after the child's birth." 113 While the 2002 Uniform Parentage Act limits the circumstances where the hold-out presumption can be attacked once established under the provisions in Sections 607 and 608 applicable to the marital presumption and estoppel, the first-two-years provision only applies to non-marital children. ${ }^{114}$

105. Id.; see also Rogers, supra note 22, at 1165-66.

106. Unif. Parentage Act, 2000 Prefatory Note, 9B U.L.A. 4 (Supp. 2003).

107. See Robinson \& Paikin, supra note 21, at 24.

108. Unif. Parentage Act, 2000 Prefatory Note, 9B U.L.A. 4 (Supp. 2003). In 2001, Texas, which had incorporated only part of the 1973 Uniform Parentage Act, was the first state to adopt the 2000 Uniform Parentage Act. John J. Sampson, The Top Ten Things that Happened in Family Law, 64 Tex. B.J. 764 n.14 (2001); see also Roberts, supra note 15, at 44.

109. Unif. Parentage Act, 2000 Prefatory Note, 9B U.L.A. 4 (Supp. 2003).

110. Id. § 204(a)(1-3) (2000), 9B U.L.A. 4 (Supp. 2003).

111. Id. § 204(a)(5) (1973).

112. Id. at 2000 Prefatory Note, 9B U.L.A. 4 (Supp. 2003); id. § 204(a)(5) (2000).

113. Id. § 204 Comment (2000), 9B U.L.A. 14 (Supp. 2003).

114. $I d$. 
Most states that create a presumption of paternity based on a hold-out provision do so similar to the 1973 Uniform Parentage Act. ${ }^{115}$ For example, Nevada's hold-out provision, typical of most states, provides that a man is presumed to be the "natural father" of a child when "he receives the child into his home and openly holds out the child as his natural child . ..."116 In addition, many hold-out provisions include language allowing a presumption of paternity if the father holds the child out while the child is "under the age of majority." 117 However, with limited exceptions, the provisions require that the father live with the child in order to establish the presumption of paternity. ${ }^{118}$ Some states do not have hold-out provisions in their parentage laws, ${ }^{119}$ further limiting families and parentage to the marital presumption and biological preferences.

\section{Holding Out the Relationship: Estoppel Provisions}

Non-traditional and non-biological families' only legal recognition exists under limited paternity estoppel ${ }^{120}$ and non-traditional hold-out provisions. ${ }^{121}$

115. See Ala. Code § 26-17-5(a)(4) (1992); Cal. Fam. Code § 7611(d) (West 1994); Colo. Rev. Stat. Ann. § 19-4-105(1)(d) (LexisNexis 2003); Mont. Code Ann. § 40-6-105(2003); Nev. Rev. Stat. 126.051(1)(d) (Michie 1998); N.J. StAT. ANN. §9:17043(a)(5)(West 2002) (providing that the fathermust hold out and support the child); N.D. CENT. CODE § 14-17-04(1)(d) (1997).

116. Nev. Rev. Stat. 126.051(1)(d) (Michie 1998).

117. See Colo. Rev. Stat. AnN. § 19-4-105(1)(d) (LexisNexis 2003).

118. See supra notes $116-17$ and accompanying text.

119. Arizona, North Carolina, Ohio, Rhode Island, Virginia and Washington do not appear to have presumptions of paternity when fathers hold out children as their biological offspring. While Ohio's parentage laws do not contain a specific hold-out provision, they do prevent relief from a final paternity adjudication where the father knew he was not biologically related to the child but acknowledged or admitted paternity, placed his name on the child's birth certificate or married the child's mother-similar to common law estoppel principles. OHIo Rev. Code AnN. § 3119.962(2) (West 2000).

120. "Paternity by estoppel is derived from the doctrine of equitable estoppel. Equitable estoppel bars a person who made a misrepresentation from denying the truth of that statement if doing so would harm another person who relied on the representation to his detriment." Kaplan, supra note 24, at 73 ; see also Rogers, supra note 22, at 1158 . Res judicata is not addressed in this article because it is based on an adjudicated paternity rather than on the merits of the relationship, even though some courts address the merits. See Marriage/Children of Betty L.W., 569 S.E.2d 77, 82 (W. Va. 2002) (finding that res judicata barred the father from re-litigating paternity since he did not challenge paternity at the time of the divorce proceeding).

121. See Pa. Cons. Stat. Ann. § 5102(b) (West 2001). The Pennsylvania hold-out provision differs from the 2002 Uniform Parentage Act and other states in that it provides two ways to create a paternity presumption when there are no biological ties to the child but when the father holds the child out to be his child, including: 1) when the child lives with the father; or 2) when the father provides financial support for the child. Id. Alabama's hold-out provision also provides two options for establishing a presumptive father where there is no marriage between the father and mother or the child is not biologically related to 
However, because estoppel principles are deemed equitable and include factors that require the courts to consider paternity challenges or claims on a case-by-case basis, unwilling fathers and courts often view estoppel as a technicality that should be applied sparingly. ${ }^{122}$

The 2002 Uniform Parentage Act estoppel principles address the child's interests by setting forth factors courts must consider when denying DNA testing, the only way available to rebut presumptive fatherhood. ${ }^{123}$ For example, Section 608 of the 2002 Uniform Parentage Act gives the court discretion to deny genetic testing in any case where either parent's conduct estops the parent from denying parentage and it would be "inequitable" to disestablish the father-child relationship. ${ }^{124}$ The court must consider the best interests of the child in determining whether to estop the parent from contesting an existing parental role or establishing biological parentage when the child has an existing father or mother relationship. ${ }^{125}$

The factors considered in estoppel cases include the length of time the party waited to contest or establish paternity after obtaining information about the child's biological parentage; the length of time the existing father-child relationship has existed; the facts surrounding the discovery of the existence or lack of a biological relationship; the nature of the existing father-child relationship; the child's age; the potential harm to the child in ending the existing father-child relationship; the nature of the relationship with the biological father; the ability of the biological father to establish child support obligations against the biological father; and any other factors affecting the existing father-child relationship or harm to the child. ${ }^{126}$

The most common situation in which estoppel should be applied arises when a man knows that a child is not, or may not be, his genetic child, but the man . . . accepted his role as child's father and both the mother and the child have relied on that acceptance. Similarly, the man may have relied on the mother's acceptance of him as the child's father.... ${ }^{127}$

\footnotetext{
the father, including: 1) when the child lives with the father; or 2) when the father holds the child out as his biological offspring. ALA. Code $\S 26-17-5$ (a)(4) (1994).

122. See K.A.T. v. C.A.B., 645 A.2d 570, 571-72 (D.C. 1994).

123. Unif. Parentage Act § 608(b)(1-9) (2000), 9B U.L.A. 27 (Supp. 2003); see also Kaplan, supra note 24, at 74; Roberts, supra note 15, at 59; Rogers, supra note 22, at 1169.

124. Unif. Parentage Act $\S 608(a)(1-2)$ (2000), 9B U.L.A. 26 (Supp. 2003).

125. Id. § 608(b)(1-9) (2000), 9B U.L.A. 27 (Supp. 2003).

126. See id.

127. Id. at Comment (2000), 9B U.L.A. 27 (Supp. 2003); see also Glennon, supra note 12, at 580; Roberts, supra note 15 , at 55.
} 
Paternity estoppel protects the existing family and father-child relationship by acknowledging parent-child relationships built on social, psychological and emotional ties rather than biology. ${ }^{128}$ However, for paternity estoppel to exist under the 2002 Uniform Parentage Act, the father must either be married to the child's mother or both hold out the child as his own and cohabitate with the child during the first two years of the child's life. ${ }^{129}$

For example, in Hubbard v. Hubbard, ${ }^{130}$ J.M. v. S.M., ${ }^{131}$ Pietros v. Pietros, ${ }^{132}$ and Scott v. Scott, ${ }^{133}$ the Alaska, Massachusetts, Rhode Island and Delaware courts all found that estoppel principles applied to paternity challenges by fathers who were married to their children's mothers and knew that their children were not biologically related to them but developed a relationship with the children. In those cases, the fathers' relationships with the children's mothers, as former-husbands who lived with the mothers and children, prohibited them from contesting the children's parentage at the time of divorce or in subsequent proceedings. ${ }^{134}$ Although the Hubbard, J.M., and Pietros courts each relied on different theories of paternity estoppel, Hubbard requiring proof of financial harm to the child over the lesser emotional harm standard applied in prior Alaska decisions, ${ }^{135}$ and Pietros applying a financial and emotional reliance standard ${ }^{136}$ all three involved divorced fathers seeking to disestablish the father-child relationship that was fostered during the marriage. ${ }^{137}$

128. See Theresa Glennon, Expendable Children: Defining Belonging in a Broken World, 8 DuKE J. GENDER L. \& POL'y 269, 282 (2000); Rogers, supra note 22, at 1158.

129. Unif. Parentage Act $\S 204$ (2000), 9B U.L.A. 14 (Supp. 2003); see also Sandra S. v. Larry W., 667 N.Y.S.2d 632, 633 (N.Y. Fam. Ct. 1997).

130. Hubbard v. Hubbard, 44 P.3d 153 (Alaska 2002) (finding sufficient financial detriment to apply equitable estoppel where the father convinced his wife to dismiss a child support action against the child's biological parent, obtained a consent from the biological father to adopt the child, and placed his name on the child's birth certificate).

131. J.M. v. S.M., No. 99-P-0719, 2001 WL 721831 (Mass. App. Ct. June 27, 2001) (estopping father from denying paternity where he knew child was not biologically related to him before the child's birth because the father had a vasectomy almost seven years before the child was conceived).

132. Pietros v. Pietros, 638 A.2d 545, 547-48 (R.I. 1994).

133. Scott v. Scott, No. C-9527, 1983 WL 35759 (Del. Super. Ct. Oct. 28, 1983).

134. See Hubbard, 44 P.3d at 157; Pietros, 638 A.2d at 547-48; J.M., 2001 WL 721831 at*3.

135. Hubbard, 44 P.3d at 156.

136. Pietros, 638 A.2d at 547.

137. See Zadori v. Zadori, 661 A.2d 370, 372 (Pa. Super. Ct. 1995) ("Paternity by estoppel may be established when a putative father marries the mother, holds the child out as his own and lists his name as the father on the birth certificate."). 
Once paternity estoppel is limited to families where there is a marital relationship between the parents or a father-child relationship during the first two years of the child's life, it excludes a whole range of fathers who may not establish a family by becoming a father to the child until after the child's second birthday or may have no relationship with the child's mother. Even when the father establishes a familial relationship with his child during those first two years of life, or longer, if that father lacks a biological connection to the child and did not live in the same house as the child during those two years, the child, father and family have no statutorily-protected paternal rights.

This situation could arise in a variety of contexts, especially if the father and mother are both minors when the child is born and they each live with their respective parents until after the child's second birthday, or two adult parents choose to wait before living together to ensure they are ready for a more permanent relationship but later cohabitate as a family and raise the child together. If it turns out the father is not biologically related to the child, either he or the child's mother can disestablish the familial relationship by dissolving the adult relationship and requesting genetic testing. A father who has lived with his child, or never lived with the child but played an active role in the child's life can be frozen out of the family because parentage laws fail to value familial and parental relationships outside the context of marital or like relationships.

For example, in Sandra $S .{ }^{138}$ the father was allowed to deny paternity even though he had a ten-year parent-child relationship with the child because he was neither married to the child's mother nor was he biologically-related to the child. Reasoning that there was no legally recognized relationship to protect between the father and child or father and mother, the court held that the father was not equitably estopped from denying paternity. ${ }^{139}$ Relying on the lack of a marital or biological relationship that would invoke the application of the equitable estoppel doctrine, the New York family court articulated the policies the courts deem entitled to protection under estoppel principles-preserving the marital family or providing for the financial security of one's biological offspring.

The Shipley v. Shipley ${ }^{140}$ court also looked to the legally protected relationship in determining a paternity dispute. There, rather than seeking to disestablish paternity of a biologically-unrelated child, the father sought to

138. Sandra S. v. Larry W., 667 N.Y.S.2d 632, 634 (N.Y. Fam. Ct. 1997).

139. $I d$.

140. Shipley v. Shipley, No. 224104, 2000 WL 33406540 (Mich. Ct. App. Oct. 20, 2000). 
preserve the relationship with his seven-year-old son, who was born ten months before the father married the child's mother, but was not the father's biological child. ${ }^{141}$ Although the child's mother stipulated to the father's role in his son's life and agreed to visitation rights at the time of the divorce, she later sought to terminate the established paternity rights when the father sought primary custody of his son. ${ }^{142}$ Finding that the father was not the child's equitable parent because the child was not born during the father's marriage to the child's mother, the court relied on the adult-adult relationship rather than the parent-child relationship in finding that the mother was not equitably estopped from challenging the father's paternity. ${ }^{143}$

In Shipley, even though the father was married to the child's mother within ten months of the child's birth, he was not afforded the protections of either the familial relationship through the marriage or the seven-year parentchild relationship because there was no biological relationship with the child.

In contrast, in Wright v. Newman, the Georgia Supreme Court estopped a father similarly situated to the father in Sandra $S$., who was neither biologically related to the child nor married to the child's mother, from denying paternity of the child where he maintained a ten-year parent-child relationship, reasoning that the father's actions in placing his name on the child's birth certificate, allowing the child to believe he was the child's biological father, and developing a father-son relationship, stopped the child from pursuing a relationship with his biological father. ${ }^{144}$ The court found that both the child's mother and the child relied on Wright's promise when he placed his name on the child's birth certificate knowing he was not biologically related to the child and then maintained a father-son relationship with the child. ${ }^{145}$

Reasoning that when the child's mother refrained from seeking child support from the biological father, she relied on Wright's promise to support the child to her detriment. ${ }^{146}$ While the court acknowledged the adult-based interest, it also acknowledged that when the child's mother relied on the

141. Id.; see also Multari v. Sorrell, 287 N.Y.S.2d 238, 239-40 (N.Y. App. Div. 2001) (ruling that a non-biological father who lived with the child for six years, beginning when the child was eighteen months old, and formed an eight year relationship with the child was not entitled to apply the doctrine of equitable estoppel to establish a father-child relationship when the non-biological father never married the child's mother and the non-biological father never formally attempted to adopt the child).

142. $I d$.

143. $I d$.

144. Wright v. Newman, 467 S.E.2d 533, 534-35 (Ga. 1996).

145. Id. at 535 .

146. $I d$. 
father's promise, her son also lost the opportunity to develop an emotional and financial relationship with his biological father. ${ }^{147}$

The J.C. v. J.S. ${ }^{148}$ court also held that a father could be estopped from denying paternity in the absence of presumptive paternity. Applying Pennsylvania's hold-out provision in the context of the estoppel doctrine, the court found that even though the marital presumption no longer existed to create a presumption of paternity where the parties were divorced at the time of the paternity contest, because the father held the child out as his biological child, he could not deny paternity when he continued to hold the child out as his own after learning the biological truth about the child's parentage. ${ }^{149}$ There, the court applied public policy that: "[C]hildren should be secure in knowing who their parents are.... [T] he child should not be required to suffer the potentially damaging trauma that may come from being told that the father he has known all his life is not in fact his father." 150

Distinguishing jurisdictions that refuse to apply paternity estoppel because it could potentially discourage fathers from participating in their biologically-unrelated children's lives to avoid becoming permanently responsible for the children, the court reasoned that the father could not reap the benefits of fatherhood without undertaking the corresponding responsibilities. ${ }^{151}$

Unlike Sandra S. and Shipley, the Wright and J.C. courts considered the child's interests as well as the family's, in the one instance taking into account the financial impact the decision would have on the family and in the other, considering the emotional trauma the child would suffer. ${ }^{152}$ When the child's interests are considered, some jurisdictions apply the doctrine based on the financial harm to the child if paternity is disestablished while other courts look

147. Id.

148. J.C. v. J.S., 826 A.2d 1, 3, 5 (Pa. Super. Ct. 2003); see also Warfield v. Warfield, 815 A.2d 1073,1076 (Pa. Super. Ct. 2003) (holding that the father was estopped from contesting the paternity of his thirteen-year-old child more than four years after he learned that his child was not biologically related to him, reasoning that "estoppel in paternity actions is aimed at 'achieving fairness as between the parties by holding them ... to their prior conduct regarding paternity of the child"') (quoting Fish v. Behers, 741 A.2d 721, 723 (Pa. 1999) (internal citations omitted)). 2002)).

149. See J.C., 826 A.2d at 3-4 (quoting Hamilton v. Hamilton, 795 A.2d 403, 405 (Pa. Super. Ct.

150. Id. at 4 (quoting Hamilton v. Hamilton, 795 A.2d 403, 405 (Pa. Super. Ct. 2002)).

151. Id. at 5 .

152. J.C., 826 A.2d at 4 (noting that estoppel is based on the security of the child in knowing who his or her parents are and protecting the child from damaging trauma); Wright v. Newman, 467 S.E.2d 533, 535 (Ga. 1996) (noting that the mother's reliance on the non-biological father was to her financial detriment). 
to the child's emotional harm due to the loss of the father-child relationship. ${ }^{153}$ When the relationship is the focus of the analysis, and when the child's best interests are maintained by preserving the father-child relationship, estoppel applies. ${ }^{154}$

\section{Returning to Biology to Define Families and Identify Fathers}

There is a movement towards, and, in some sense, a return to, a biological preference in parentage laws. This occurs when biological truths are preferred over relationships, including marriage, as when parentage laws allow genetic testing to overcome the marital presumption. While the marital presumption is also grounded in an assumption based on biology, a biological certainty, through genetic test results, acts as clear and convincing evidence to rebut the marital presumption, which is the only potential family relationship that is protected without a genetic relationship between the parents and child. Therefore, by allowing certainty in biology to rebut presumed biology, nontraditional families where biology is not the basis for the parent-child or familial relationship are even more at risk because they rest on neither certain nor presumed biological truths.

Likewise, when fathers presumed by marriage with existing father-child relationships are permitted to challenge the paternity of their children based on the lack of a biological tie to the children, even within confined periods of time, biology takes precedence over the family or parent-child relationship. ${ }^{155}$ Finally, because paternity fraud laws allow biology to rebut any relationship, a return to a biological preference further illegitimizes non-traditional families

153. See Wright, 467 S.E.2d at 535; J.C., 826 A.2d at 4; see also Natalie A. Minton, Equitable Estoppel Precludes Husband in Divorce Proceeding from Refuting Paternity to Avoid Child-Support Payments-Pietros v. Pietros, 638 A.2d 545 (R.I. 1994), 29 SuffolK U. L. Rev. 625, 626-27 nn.17-18 (1995) (discussing a mother's detrimental reliance on a non-biological father's representations); Rogers, supra note 22, at 1158-60.

154. See Rogers, supra note 22 , at 1160 . However, when the courts look at the financial detriment to the child, the availability of a biological father who can support the child may be considered. See Smith v. Dep't of Human Res., 487 S.E.2d 96 (Ga. 1997) (noting that there is no legitimate reason to enforce the legal fiction of paternity when a child is already receiving public support and the petitioner is a government agency).

155. See Colo. Rev. Stat. § 19-4-107(1)(b) (2003); Tex. Fam. Code Ann. § 160.607(a) (Vernon 2002); Wyo. Stat. AnN. § 14-2-603(a)(i), (iii) (LexisNexis 2003). For example, Wyoming and Colorado require a father to deny paternity within a reasonable time after obtaining knowledge that the child may lack the preferred biological tie to the father, however, those states require the father to contest paternity before the child reaches the age of five. See Colo. Rev. Stat. § 19-4-107(1)(b) (2003); Wyo. Stat. Ann. $\S 14-2-807$ (a) (LexisNexis 2003); see also Stewart v. G.M. (Interest of K.B.), 490 N.W.2d 715, 717 (N.D. 1992) (noting that an action must be brought within five years of the birth of a child). 
by placing them in jeopardy whenever a biological connection between a parent and child is lacking.

\section{A. When Biology Defeats Marriage}

A father may challenge his paternity under the marital presumption at the time of divorce through biology trump laws. ${ }^{156}$ While the marital presumption is still given effect under these laws, the father can challenge the marital presumption at the time of divorce or within a certain time period, usually two to four years after the child's birth, either by proof that he is not the biological parent of the child or that another man is. ${ }^{157}$ Typical biology trump laws provide that " $[\mathrm{t}]$ he presumption of legitimacy of a child born during wedlock is overcome if the court finds that the conclusions of all the experts, as disclosed by the evidence based upon the tests, show that the husband is not the father of the child." ${ }^{58}$ Because biology trump laws rely on the assumption that there is no family to protect once the marital relationship between the child's parents ends, they classify all but intact marriages as unprotected families, subject to paternity challenges based on nature over nurture.

For example, both the Cochran v. Cochran ${ }^{159}$ and Gann v. Gann, ${ }^{160}$ courts allowed nature to prevail once the marital relationship deteriorated. ${ }^{161}$ When the fathers were allowed to challenge the parentage of their children through genetic evidence, which demonstrated that the fathers lacked biological relationships with their children, the courts allowed the fathers to challenge not only the child's relationship with the father, but also the existence of a family. ${ }^{162}$

In Cochran, the Indiana appellate court ordered DNA tests during the dissolution of the marriage to determine the parentage of the couple's two young children. ${ }^{163}$ When the test results excluded the husband as the father of the youngest daughter, the court found that he had no legal relationship with

156. See N.H. Rev. Stat. Ann. § 522:5 (1997); Okla. Stat. Ann. tit. 10, §§ 504B, 505 (West 1998); 23 Pa. Cons. Stat. Ann. § 5104(g) (West 2001); see also Chezem \& Nagy, supra note 16, at 469; Kaplan, supra note 24, at 79-80.

157. See statutes cited supra note 156.

158. N.H. Rev. Stat. AnN. § 522:5 (1997).

159. Cochran v. Cochran, 717 N.E.2d 892, 893 (Ind. Ct. App. 1999)

160. Gann v. Gann, 705 So. 2 d 509 (Ala. Ct. App. 1997).

161. See Cochran, 717 N.E.2d at 894-95; Gann, 705 So. 2 d at 511.

162. See Cochran, 717 N.E.2d at 894-95; Gann, 705 So. $2 d$ at 511.

163. Cochran, 717 N.E.2d at 893. 
his youngest child in spite of the existing parent-child relationship. ${ }^{164}$ While acknowledging that biology is not the only criteria for paternity, the court reasoned that given the policy considerations of correctly identifying a child's parents, a child could not be born of the marriage unless there was a biological tie to the child or the child was adopted by both parents. ${ }^{165}$ However, while the court conceded that a relationship between the father and child existed, it failed to acknowledge the existence of a family after the parties divorced, limiting the relationships to those founded on biology.

Likewise, the Gann court also allowed the father to use biology to rebut the marital presumption. ${ }^{166}$ Applying the clear and convincing evidence standard to rebut the marital presumption, the court held that DNA "evidence that tends to "show that it is naturally, physically, or scientifically impossible for the husband to be the father" "rebutted the presumption. ${ }^{167}$ In doing so, the Gann court discounted the ability of a family to survive divorce.

In contrast, the Gilbert A. v. Laura A. ${ }^{168}$ and Lloyd v. Lloyd ${ }^{169}$ courts applied the marital presumption and child's best interests, respectively, over biological challenges to paternity where the fathers wanted to maintain their relationships with the children. For example, in Gilbert A., the father sought to enforce visitation rights, which the children's mother terminated after she unsuccessfully attempted to increase the father's child support payments. ${ }^{170}$ There, the appellate court held that the trial court erred when it improperly found that the father was a "legal stranger" to his son since he admitted a lack of a biological father-son relationship. ${ }^{171}$ Relying on the child's birth during the marriage and the father's relationship with the child, including objective criteria such as signing the child's birth certificate, and assigning the child his father's surname, the court held that the father was entitled to offer proof of extraordinary circumstances, the standard for custody or visitation of a nonbiological parent in New York. ${ }^{172}$

Limiting the definition of family to intact marriages excludes the majority of relationships that exist in the lives of children today. As neither Cochran nor Gann considered the child's interest in maintaining the familial and

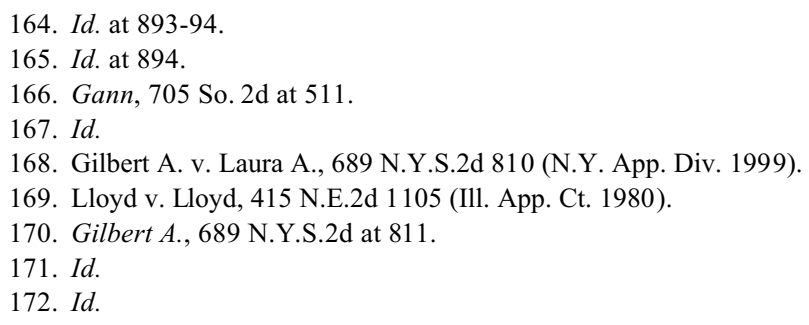


parent-child relationships with the non-biological fathers, neither court considered the ability of the family to continue post divorce. Rather, biology was given preference over the financial, social and psychological interests of the families and children, assuming families are tied to biology ${ }^{173}$ and reaffirming the biological underpinnings of the marital presumption. Furthermore, neither court considered the impact on the children of allowing the fathers to engage in father-child relationships until they no longer desired to play daddy.

In contrast, while the Gilbert $A$. court recognized that "psychological parenthood" of a non-biological child is not normally enough to demonstrate an extraordinary circumstance warranting visitation, where the child's mother encouraged the father-son relationship, the court acknowledged that extraordinary circumstances could exist to establish parentage. ${ }^{174}$

Likewise, the Lloyd court upheld an award of custody to a non-biological father who was only briefly married to the child's mother more than five years after his birth and only lived with both his son and the child's mother for one year but lived with his son alone for all but one year of the child's life. ${ }^{175}$ When the father was at work, the child's mother took the child and moved to Cincinnati, where the father subsequently found them with the assistance of private detectives. ${ }^{176}$

While acknowledging that a biological parent is presumed to be entitled to custody over a non-biological parent, the court reasoned that the right is not absolute, requiring the court to consider the best interests of the child considering the facts and circumstances of each case. ${ }^{177}$ Based on the fatherson relationship and lack of evidence about the child's mother's home, the court held that it was in the best interests of the child to remain with his father. ${ }^{178}$

By considering the children's relationships to their fathers, the Gilbert A. and Lloyd courts looked beyond the fathers' relationships with the children's mothers and biology as a means to establish a family. In Lloyd, the child wanted to live with the non-biologically related father, which was at least

173. See supra notes 163-67 and accompanying text; see also Lane v. Lane, 912 P.2d 290 (N.M. Ct. App. 1996) (weighing arguments regarding the non-biological father's status in an artificial insemination case when signed consent could not be conclusively proven). claim).

174. Gilbert A., 689 N.Y.S.2d at 887-88 (encouraging the father to make an equitable estoppel

175. Lloyd v. Lloyd, 415 N.E.2d 1105, 1106 (Ill. App. Ct. 1980).

176. $I d$.

177. Id. at 1107 .

178. $I d$. 
considered by the court. While the Gilbert A. and Lloyd courts were not faced with deciding the children's paternity, both addressed attacks on the fathers' rights based on a lack of a traditional family or biological relationships to the children.

If faced with a legal determination of paternity, the Gilbert $A$. and Lloyd courts could apply the same criteria and find in favor of legitimizing the father-child relationships and families as the same facts that supported visitation and custody rights should support recognition of fatherhood.

\section{B. When Biology Is the Absolute Truth}

Paternity fraud laws and other similar laws also identify fathers based on biology and limit families not only to those that involve intact marriages, but also to those intact marriages where both parents are biologically related to the child. In doing so, paternity fraud laws privilege biology over all forms of families and fathers by allowing challenges to paternity at a reasonable time after learning that the child may be a biological stranger. ${ }^{179}$

Not only do paternity fraud laws remove the financial responsibilities of fatherhood and membership in a family, they also limit the definition of family and fatherhood to those situations where biology forms the relationships within the families.

Likewise, common law concealment or fraud principles also allow fathers to set aside familial and father-child relationships when there is no biological relationship with the child. Those cases allow fathers to set aside paternity judgments when the mother fraudulently conceals the identity of the child's father, which is consistent with most paternity fraud laws. ${ }^{180}$ Because the laws pit fathers against mothers, they set the groundwork for destruction of the family unit by dividing the most important people in the child's life- the child's parents.

179. Id.

180. See Marriage of M.E., 622 N.E.2d 578, 581-82 (Ind. Ct. App. 1993) (setting aside the paternity determination based on the mother's extrinsic fraud under Indiana Rule of Trial Procedure 60(B)(3)); Dep't of Soc. Servs. v. Franzel, 516 N.W.2d 495, 496-97 (Mich. Ct. App. 1994) (setting aside a support order as no longer equitable under Michigan Court Rule section 2.612(C)(1)(e)); Libro v. Walls, 746 P.2d 632, 634 (Nev. 1987) (overturning a lower court decision awarding child support due to mother's concealment of paternity); White v. Armstrong, No. 01A01-9712-JV-00735, 1999 WL 33085, at *3 (Tenn. Ct. App. Jan. 27, 1999) (applying Tennessee Rule of Civil Procedure 60 to a judgment deemed no longer equitable); see also Williams v. Williams, 843 So. 2d 720 (Miss. 2003); Rafferty v. Perkins, 757 So. 2d 992 (Miss. 2000). 
For example, in Libro v. Walls, ${ }^{181}$ the court held that the father could set aside an eight-year-old paternity judgment where blood tests proved the father was not the child's biological father. ${ }^{182}$ Five years earlier, the father learned that genetic test results excluded him as the child's father when he submitted the child and himself to genetic testing a year after the adults divorced. ${ }^{183}$ The court held that the wife's failure to disclose the child's biological parentage to the husband constituted extrinsic fraud warranting relief from the paternity determination even though he knew for years that he was not the child's biological father and did not challenge paternity during that time. ${ }^{184}$ The court reasoned that the mother had a duty to inform her husband that his child may not be biologically related to him, reasoning that "[w]here the fraud is so successful the other party is not even aware he has a claim or defense, it may be said he had no reasonable opportunity to present it."185

Portraying the father as a victim in the mother's scheme, who was "lulled by ignorance of the true facts," the Nevada Supreme Court further reasoned that equitable relief allowed the earlier judgment to be set aside. ${ }^{186}$ When the court held the judgment could be set aside because the father was unaware of the mother's scheme to conceal the identity of the child's biological father, the court furthered the presumption that the family is defined, as is the father, by biological connections between the parents and child rather than by their relationships. In doing this, the court moved biology to the forefront of paternity legislation.

Likewise, the court in DeRico v. Wilson ${ }^{187}$ allowed a father to renounce his parent-child relationship in a paternity challenge brought two years after the children's paternity was adjudicated. There, the court reasoned that because the former wife fraudulently concealed the biological paternity of two of the couple's three children, the father was entitled to disestablish the paternity of his six-and four-year-old children. ${ }^{188}$ Reasoning that the father had no obligation to support children who he neither adopted nor had a biological relationship with, the court remanded the case for a determination

181. 746 P. $2 \mathrm{~d} 632$

182. Id. at 633-34

183. Id. at 633 .

184. Id. at 634 .

185. $I d$.

186. Id. at 633-34.

187. DeRico v. Wilson, 714 So. 2d 623, 624 (Fla. Dist. Ct. App. 1998), overruled by D.F. v. Dep’t of Revenue, 823 So. $2 \mathrm{~d} 97$ (Fla. 2002) (finding by the Florida Supreme Court that final paternity judgments must be attacked within one year of the ruling even in the case of fraud).

188. Id. 
of the amount of reimbursement of child support paid to the children's mother. ${ }^{189}$ The dissent argued that there was no fraud justifying setting aside the paternity adjudication because the children's mother was not certain as to the children's biological parentage. ${ }^{190}$ In addition, the dissent relied on the father's relationship with the children since the paternity adjudication and the two-year delay in bringing the petition to set aside paternity in arguing that it was not in the children's best interest to allow the father's paternity challenge to prevail. ${ }^{191}$

Allowing the fathers in Libro and DeRico to rebut an established familial and parent-child relationship, whether at the time of divorce, a specified period during the marriage, or even within a specific number of years after the child's birth, disregards the importance of the parent-child relationship and family in the child's life. Instead, parentage laws focus on the conduct of the child's mother to the child's detriment.

In Ince $v$. Ince, ${ }^{192}$ the court made the right decision for the wrong reason. ${ }^{193}$ There, the father asked the court to allow genetic testing on his teenage daughter to determine whether she suffered from a genetic problem, claiming the testing was necessary for medical reasons. ${ }^{194}$ When the tests excluded the father as a biological parent of his daughter, he filed a petition for a bill of review seeking to set aside the paternity adjudication of his teenage daughter. ${ }^{195}$ The Ince court denied the father's request to set aside the paternity adjudication, indicating that the marital presumption created a legal relationship between the father and child which should not be defeated by biology alone. ${ }^{196}$ The court reasoned that "[b]eing a parent has always meant more than simply proving the DNA necessary to create human life originated from a particular individual." 197

Unlike Libro and DeRico, when the Ince court denied the father's paternity challenge based on a lack of a biological relationship with his child, the court employed a pseudo-child-centered approach to an adult-centered issue by acknowledging that fathers are created by more than sperm donation and that an existing relationship should be acknowledged. While the Ince

189. $I d$.

190. Id. at 625 (Harris, J., dissenting).

191. Id.

192. Ince v. Ince, 58 S.W.3d 187 (Tex. Ct. App. 2001).

193. $I d$.

194. $I d$.

195. Id.

196. Id. at 191.

197. Id. 
court addressed the father's paternity in the context of the legal relationship established by the father's marriage to the child's mother, the child's relationship with the father was also protected. Unfortunately, because the court failed to address the father-child relationship as the legally-protected relationship, the court reached the right decision for the wrong reason. It is the relationship of the father to the child, not his former relationship with the child's mother, that identifies him as a father and the three of them as a family. Ince's identity as the child's father is not dependent on the fact that he married the child's mother, but rather on the fact that he contributed to his child's development and continued to do so until he chose to contest paternity, which could have destroyed the family and father-child relationship had the court allowed him to desert his family and child.

\section{What Went Wrong}

When paternity laws attempt to create absolutes based on biology and presumptions that arose out of perceived biological truths, the laws not only fail to address the needs of existing family relationships, but also favor adult interests over those of the children, to the detriment of the child and family.

The problems inherent in the biology and traditional family preferences include: 1) favoring an adult-centered approach to paternity over a childcentered approach; 2) encouraging fathers to end their relationships with their children as a pre-requisite to terminating the financial obligations of parenthood; 3) discounting the value of functioning non-traditional families; and 4) allowing biologically-related strangers to replace established fathers. The solutions all lie in resolving the first issue - placing the child's interests over the adults' and acknowledging that families and fathers are defined by the child's relationships with her parents, not the parents' relationships with each other.

\section{A. Assumes Adult-Centered Over Child-Centered Law}

Where the courts look to biology to provide the answers in parentage cases, they inevitably look to the adult relationships that biology fosters and the biological offspring that arise out of those adult relationships. The child is just a byproduct in this process, relegated to the consequences of the adults' actions. The predominant means of promoting an adult-centered biological approach is the courts' focus on the interests of the adults involved in the family, either by emphasizing the adults' reliance or rights arising out of the biological connection to the child. In addition, the courts' own language 
evidences the preference for adult-adult relationships over parent-child relationships.

Even when the courts proclaim to consider the child's interests, they often belie the proclamation with words and actions that focus on the adults' interests over the child's. For example, in Sandra S., the New York family court focused on the adult relationships and adult interests to the detriment of the child's interests when it allowed a father of ten years who lacked a biological relationship to the child or marital relationship with the child's mother to deny paternity. ${ }^{198}$ In addressing the equitable estoppel doctrine asserted by the child's mother in the filiation action, the court described the burden of proof as requiring the child's mother to establish that the father engaged in conduct amounting to a false representation and that she relied on his conduct to change her position. ${ }^{199}$

The court acknowledged the mother's argument that she relied on the father's representations that he would stand by her, but found that her contention that he knew he was not biologically related to the child at the time she was pregnant did not impute knowledge to the father, who denied knowledge of the child's biological parentage as the mother "never directly told [the father] . . that Jordan was not his child." ${ }^{200}$ In fact, the court attributed the father's relationship with the child and the "quality of the care" he provided as evidence that the father believed he was biologically related to the child when he undertook the responsibilities as the child's father. ${ }^{201}$

In addition, while criticizing the father's complete withdrawal from his child's life, the court reasoned that since the father's relationship with his son was strained as a result of the litigation and he had no contact with the child for over a year, the court could not force a father to maintain a parental relationship that no longer existed. ${ }^{202}$ The court also focused on the mother's misrepresentation in her filiation petition that the father was biologically related to the child to deny her equitable estoppel claim. ${ }^{203}$

The court's reasoning suggests that the father would not have undertaken a relationship with the child but for a biological connection. Further, it discounts that fathers do not have to be biologically related to their children to love, support or care for them. It also suggests that the parent-child

198. See Sandra S. v. Larry W., 667 N.Y.S.2d 632, 635 (N.Y. Fam. Ct. 1997).

199. See id. at 634.

200. $I d$.

201. Id.

202. See id. at 635 .

203. See id. 
relationship is evaluated from the father's point of view rather than the child's. Since the father claimed he believed there was a biological relationship with his child, the child presumably knew him as a father, loved him as a father, and relied on him for emotional, financial and psychological support as a father. The court's failure to consider the child's perspective in defining the father-son relationship evidences the preference for addressing families and paternity from an adult-centered approach.

The court further evidenced its adult-centered perspective in defining the burden of proving estoppel from the mother's reliance on the father's representations rather than the child's reliance on the father's almost certain representations to the child. ${ }^{204}$ The adult-centered analysis continued when the court focused on the father's desire to end the parent-child relationship, rather than addressing the child's interest, if any, in maintaining a father-son relationship.

Likewise, when courts refuse to apply equitable estoppel principles based on a father's lack of knowledge of the child's biological parentage, they find that it would be unfair to hold the father liable for years of child support for a child with whom he has no biological relationship. ${ }^{205}$ The rationale is furthered by the belief that the child's mother deceived the father, ${ }^{206}$ and that the child's mother should not profit from her fraudulent acts. ${ }^{207}$

When the courts and parentage laws focus on the detriment to the father in supporting a child that is biologically unrelated to him, they approach families, fatherhood and parentage from an adult-centered perspective, ignoring the best interests of the child by denying him the only father he has ever known and causing him to endure emotional, as well as financial hardship. ${ }^{208}$

The District of Columbia appellate court articulated the distrust of paternity estoppel principles in K.A.T. v. C.A.B., where the father sought to deny paternity of a child he held out as his biological child where there was

204. See id. at 634 .

205. See Glennon, supra note 12, at 578; see also ALA. Code § 26-17A-1(a) (Michie Supp. 2002); Alaska Stat. § 25.27.166(LexisNexis 2002); Ark. Code Ann. § 9-10-115(LexisNexis 2002); Ga. Code Ann. § 19-7-54 (LexisNexis Supp. 2003); 750 Lll. Comp. Stat. Ann. 45/7 (Lexis 1999); Iowa Code AnN. $\S 600 \mathrm{~B} .41 \mathrm{~A}(3)$ (West 2001) (section 600B.41A(3)(a)(1), limiting those who may contest paternity was ruled unconstitutional); Md. Code Ann. Fam. LaW § 5-1038(a)(2)(i)(2) (1999); Ohio Rev. Code AnN. $\S 3119.962$ (West Supp. 2003); VA. Code AnN. § 20-49.10 (Michie Supp. 2003).

206. See Smith v. Dep't of Human Res., 487 S.E.2d 94, 96 (Ga. Ct. App. 1997); Glennon, supra note 12 , at 579 .

207. See Smith, 487 S.E.2d at 96.

208. See Roberts, supra note 15 , at 55. 
no evidence that he lived with the child or shared the expenses of caring for the child during the first three years of the child's life and the child was told that he was not her father even though he was regularly involved in the child's life and bought her clothing and toys. ${ }^{209}$ After a three-year break in the adultadult relationship when the father moved out of the state but kept in touch with the child, the mother and father married. ${ }^{210}$

The K.A.T. court found that even though there was an existing parentchild relationship and the child only recently learned that K.A.T. was not her biological father, the father was not estopped from denying paternity based on a lack of a biological connection to the child. ${ }^{211}$ Reasoning that adoption is available to non-biological parents who desire to establish a legal relationship with a biologically-unrelated child, the court held that the non-biological parent was akin to a stepparent who should not be discouraged from acting in the child's interest during the relationship with the parent by making the consequences of providing emotional and financial support to a spouse's child a lifelong commitment, even after the relationship between the adults ceased. ${ }^{212}$

Courts also consider adult interests over the child's when they fail to provide the child with a voice in the parentage action or fail to consider the child's interest in maintaining the father-child relationship. For example, when the biological father in Marriage of Adams ${ }^{213}$ claimed that the child wanted to maintain his existing ten-year parent-child relationship with the non-biological parent, the court stated that the child's interests were not relevant to the determination of whether a legal parent-child relationship existed. $^{214}$

Because the law in Indiana allowed the father to rebut the marital presumption with biological evidence, the child's father was able to relieve himself of the child support obligation. ${ }^{215}$ While the concurrence indicated surprise by the father's decision to withdraw from the child's life as a result of his wife's behavior, it found that the father could do so as long as he rebutted the presumption in a timely manner. ${ }^{216}$ Although acknowledging the potential harm to the child, because the issue was brought by the alleged

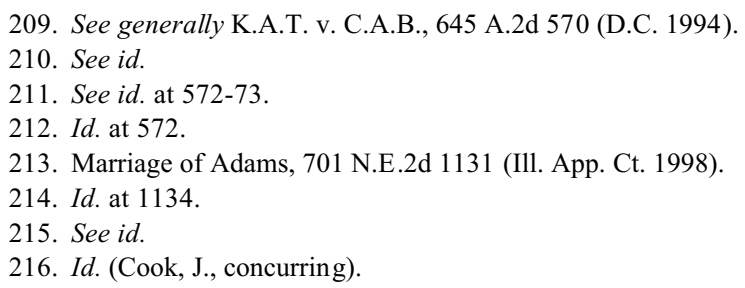


biological father in an attempt to avoid child support, the court deemed the claimed harm to the child as unreliable. ${ }^{217}$

Finally, the language used by the courts also suggests that even though the courts purport to take a child-centered approach or protect the interests of the child, they focus on the adults involved in the action rather than the children. For example, the courts refer to the detriment that would occur if financial support were lacking, but do so in the context of the mother being prejudiced by not being able to pursue the biological father for that support or the mother benefitting from receiving the support. ${ }^{218}$ The courts also fail to address the child's interest in the financial, as well as emotional, support from the existing father.

\section{B. Encourages Fathers to Leave Their Children and Families}

Another detrimental impact of viewing paternity and families through a biological lens is that fathers who want to contest paternity are encouraged to abandon their children after a long-term parent-child relationship already exists. While a father cannot be forced to love his children or provide for their support, he can be discouraged from abandoning them in order to strengthen a paternity challenge.

For example, when the Sandra $S$. court allowed a father of ten years to deny paternity when he was neither married to the child's mother nor biologically-related to the child, the court rewarded the father's behavior by relieving the father of any responsibility for the child - emotional, financial or otherwise ${ }^{219}$ - with the effect of encouraging fathers to abandon their father-child relationships to avoid the responsibilities of parenthood.

Likewise, the court in J.C. distinguished cases where the courts found that estoppel would not apply on the basis that the fathers in those cases had already abandoned their children once they learned of the lack of a biological connection with the children, whereas the father in J.C. maintained an ongoing parent-child relationship with his non-biological child. ${ }^{220}$ Rather than discouraging fathers from abandoning their children, the court distinguished cases where the parent-child relationship was terminated before the paternity challenge was brought, and sent a message to future fathers seeking to

217. Id. at 1135 .

218. See Scott v. Scott, No. C-9527, 1983 WL 35759, at*4 (Del. Super. Ct. Oct. 28, 1983); White v. Armstrong, No. 01 A01-9712-JV-00735, 1999 WL 33085, at *5 (Tenn. Ct. App. 1999).

219. See Sandra S. v. Larry W., 667 N.Y.S.2d 632, 635 (N.Y. Fam. Ct. 1997).

220. J.C. v. J.S., 826 A.2d, 1, 4-5 (Pa. Super. Ct. 2003). 
disestablish paternity that they should end their parent-child relationships to bolster their paternity challenge.

By relying on those cases to demonstrate when estoppel does not apply to paternity challenges, the Sandra S. and J.C. courts establish precedents that will encourage attorneys counseling fathers who desire to end their financial obligations to pay child support that the best way to do so is to end the emotional relationship with their children. While a father can always choose to terminate family and parent-child relationships, the courts should not reward it.

\section{Limits Families to the Marital Presumption \& Biological Ties}

Allowing biology to form the basis of determining what constitutes a legally-recognized family precludes recognition of many families that are based on the child's relationships with her parents but not on the parents' relationships with each other.

For example, the United States Supreme Court reaffirmed the biological connection to the marital presumption in Michael H. v. Gerald D., ${ }^{221}$ when it defined a family and fatherhood based on the father's relationship with the child's mother, rather than the child. Relying on the policy of preserving the integrity of the family, the court denied the biological father's claim of paternity to a child born to an intact marriage. ${ }^{222}$ While the decision to deny the biological parent's challenge to paternity furthers existing parent-child relationships, it only does so when there is a relationship with the child's mother, not the child.

In L.C. v. T.L., ${ }^{223}$ the Wyoming Supreme Court applied the majority's rationale in Michael $H$. to deny a father's paternity claim even though the father held out the child as his own, as well as cared for and lived with the child until the father's relationship with the child's mother ended. ${ }^{224}$ There, the court acknowledged that the father fell within Wyoming's hold-out provisions, making him a presumed father, but because the hold-out presumption, when weighed against the marital presumption, was rebutted by the marital presumption, the father lost any interest in his relationship with the child once his relationship with the child's mother ended. ${ }^{225}$ Even though the

221. See Michael H. v. Gerald D., 491 U.S. 110, 119-20 (1989).

222. See id. at 121-22.

223. L.C. v. T.L., 870 P.2d 374 (Wyo. 1994).

224. See id. at $378,380,382$.

225. See id. at 379-80. 
marital father was stationed abroad at the time of the child's conception and birth and separated from the child's mother before the child was seven months old, because the divorce decree indicated that the child was a product of the marriage, applying the 1973 Uniform Parentage Act language adopted by Wyoming, the court found that the marital presumption was "founded on the weightier considerations of policy and logic" than the hold-out presumption. ${ }^{226}$ The court also rejected the contention that since the marriage was no longer intact, the marital presumption no longer applied. Rather, by preserving the child's legitimacy, the court found that the marital presumption prevailed over the hold-out presumption, even without a father-child relationship. ${ }^{27}$

In addition, limiting families to those situations where the parents share a residence or cohabitate with the child further propagates a biological preference in defining families, once again tying the parental and family relationships to the biological relationship. This is especially true when the requirement of cohabitating with the child must be accomplished during the child's tender years as the assumption is that the rationale for living with the child and taking on the parental relationship is motivated by biology rather than by the parent's desire to form a lasting bond with the child.

While the law recognizes the biological parent's duty to support his child regardless of whether he lives with the child, ${ }^{228}$ it does not impose similar responsibilities on parents in non-traditional families, possibly reasoning that a non-custodial or non-cohabitating parent cannot be forced to participate in the child's daily activities or even to establish a relationship with the child. ${ }^{229}$ However, that assumption, just like the assumption that children born during a marriage are the biological offspring of the husband and wife, assumes that biology is the basis for the decision to become parents and expand the family. Because families are not constrained by biological connections and parents are motivated by love towards the child rather than genetic ties, a biological approach to parentage limits the forms of family and father-child relationships.

226. See id. at $378-79,382$.

227. See id. at 379-80.

228. See, e.g., Nolan, supra note 77, at 27.

229. For academic discussion, see Harris, supra note 63, at 483. 


\section{Allows Biological Fathers to Prevail Over Existing Father-Child Relationships}

When the possibility of a biological truth is the lens through which the courts view father-child relationships and define families, existing parentchild relationships and families are disrupted based on the testimony and speculation of the putative father claiming a biological connection to the child. ${ }^{230}$ Likewise, when biology is favored by parentage laws to allow a stranger to challenge the child's family by imposing a biological relationship on the child, the child's interests are jeopardized because it could mean the end of the only family she knows. ${ }^{231}$ Even children born in traditional families are not immune from third-party attacks on their families. However, in some cases, the alleged biological parent has to establish a relationship with the child, as well as the biological connection, to prevail on a paternity claim over the marital presumption.

The child born into a non-traditional family is less protected from biological challenges than the child born during a marriage, as biological parents generally prevail over non-biological parents where no traditional marital family or cohabitating marriage-like relationships exist. As a result, the child of a non-traditional family has two challenges to overcome-his family and his biology. Only when the biological focus is eliminated can the child's relationships with his father and family become clear to the courts, who may then provide those children with the legal protection and recognition they require.

\section{Biological Challenges to Traditional Families}

Viewing paternity and families through a biological lens, courts often allow a putative or alleged biological parent to challenge the existing parentchild relationship to the detriment of the child and his existing family. ${ }^{232}$ For

230. See infra notes $233-46$ and accompanying text.

231. See Glennon, supra note 12, at 566.

232. See generally Altenbernd, supra note 55. The Honorable Chris W. Altenbernd believes courts' inclination toward the rights of the biological father adverse to the child and his existing family has its roots in common law. Id. at 237 ("The common law never abandoned natural rights concepts for biological fathers of quasi-marital children, even long after the presumption had accomplished that practical effect."); see In re S.R.H., 981 P.2d 199, 200 (Colo. Ct. App. 1999) (finding that a biological father was entitled to maintain an action to establish paternity of the child over objections of child's mother and non-biological father); see also Comino v. Kelley, 30 Cal. Rptr. 2 d 728 (Cal. Ct. App. 1994) (refusing to allow the mother 
example, allowing a biological father to invade the sanctity of the existing family will, at the very least, cause marital disharmony, uncertainty and doubt. The child may also suffer the loss of the only father she has ever known if the third party's presence in the family causes a marital rift, especially since the marital father will have no obligation to maintain a financial or emotional relationship with the child if the biological assumption of the marital presumption is severed by a biological truth. While the biological truth is believed to create certainty, when it allows a stranger to intrude on the family and existing father-child relationship, the exact opposite is true. The child's existing family is likely to destabilize or worse-dissolve.

When a biological father pursues a paternity claim, a claim permitted in over two-thirds of the states, ${ }^{233}$ the child's parents are faced with redefining their roles in this new family dynamic. Because the putative father does not always have to establish biological paternity to bring the claim, any man who believes he has a biological connection with the child can bring a filiation action to establish paternity, regardless of the existence of a father or familial relationship. ${ }^{234}$

For example, the court in Witso $v$. Overby $y^{235}$ allowed a wife's paramour to bring an action asserting paternity of the wife's one-year-old child. ${ }^{236}$ While the wife admitted that the timing of the indiscretion was consistent with the conception of her child, the wife, along with her husband, disputed the paramour's right to obtain genetic testing in support of his claim because of

to defeat a presumption of paternity even though she was married to another man at conception because she, in part, had lived apart from her husband); G.F.C. v. S.G., 686 So. 2d 1382 (Fla. Dist. Ct. App. 1997) (concluding that proof of abuse, neglect or abandonment by the marital father are required before his rights may be terminated and the biological father lacked standing to establish paternity over the child born to the intact marriage); In re S.R.I., 602 N.E.2d 1014, 1016 (Ind. 1992) (applying public policy in identifying child's biological parents over policy favoring stability and finality of divorce adjudications); Smith v. Jones, 566 So. 2d 408, 414 (La. Ct. App. 1990) (finding that a biological father has the right to bring action to establish paternity despite the child having been legitimated by another man); B.S. v. T.M., 782 A.2d $1031,1034,1037$ (Pa. Super. Ct. 2001) (limiting irrebuttable presumption to cases involving intact and not temporarily estranged husbands and wives).

233. Dallas, supra note 26, at 373-374. Not only do two-thirds of the states permit claims by the biological father, but, under the Uniform Parentage Act, "[o]nce the court determines that genetic testing is proper, ..., the court must adjudicate the genetic father as the legal father of the child." Glennon, supra note 12, at 570 (citing the Unif. Parentage Act § 631(2), 9B U.L.A. 348 (2000) (emphasis added)).

234. See Ark. Code AnN. § 9-10-104 (LexisNexis 2002); Ind. Code Ann. § 31-14-7-2 (Michie 1997); Minn. Stat. AnN. § 257.57 Subdiv. 1(f) (West 2003); see also R.N. v. J.M., 615 S.W.3d 149, 151, 153 (Ark. 2001) (allowing an attack on paternity by a man alleging to be the biological father even though the child was legitimate).

235. Witso v. Overby, 609 N.W.2d 618 (Minn. Ct. App. 2000), aff'd, 627 N.W.2d 63 (Minn. 2001), cert. denied, 534 U.S. 1130 (2002).

236. See id. at 619-20. 
their presumptive parentage under the marital presumption, as well as their desire to maintain their existing family. ${ }^{237}$ The trial court allowed the genetic testing but sealed the results until the appellate court could address the paramour's paternity claim. ${ }^{238}$

The appellate court found that the paramour was entitled to genetic testing and the opportunity to establish the child's biological paternity, regardless of the marital status of the child's parents. ${ }^{239}$ Once genetic testing included the wife's paramour as the child's biological father, the court weighed the marital and biological presumptions against each other, considering the "blood relationships, marriage, and the best interests of the child" in determining which presumed father was determined to be the "legal" father. ${ }^{240}$ Reasoning that men would seek self help genetic testing that would be equally disruptive to the child anyway, ${ }^{241}$ the Witso court allowed the testing and the paternity challenge.

The Witso court examined the biological parent's interests without considering the child's existing parent-child relationship or the impact the genetic testing would have on the child's family. Instead, it assumed that since the putative father claimed a biological relationship with the child, he was entitled to pursue it, regardless of the impact on the child or his family. The court also failed to acknowledge that many men abandon their children once a biological truth excludes them as the child's biological parent-destroying the family and father-child relationship. Arguably, the court could have considered the possibility and deemed the non-biological father's removal from the child's life irrelevant since the biological father sought those rights and would be responsible for the child's financial support.

However, while a biological father's desire to establish a relationship with his child is admirable given the number of children without fathers, when the child already has a father, allowing a biological claim to prevail over the existing father-child relationship preferences one father over the other-in this case, the father whose only relationship stems from a mistake, an accident. ${ }^{242}$ In doing so, the court placed an adult's indiscretion over the resulting child's interest in maintaining a stable parental relationship and a functioning family.

\author{
237. See id. \\ 238. Id. at 619 . \\ 239. See id. at 622 . \\ 240. Id. at 623 . \\ 241. Id. \\ 242. See Armstrong, supra note 23 , at $398-400$.
}


Arguably, the addition of the biological father into an intact family is no different than when a parent remarries. ${ }^{243}$ However, because the relationship with the biological father in the remarriage situation already exists, a change in the mother's or father's adult relationship, while modifying the dynamics of the child's family, does not alter the child's existing parental relationships. Instead, it realigns existing relationships. When a third party raises a challenge, however, adding a new father to the family is far more than merely realigning the existing relationships. It introduces a foreign element to an existing family, which has the potential to, and usually does, destroy the existing family.

\section{Biological Challenges to Non-Traditional Families}

Non-traditional families are even more at risk for third party intrusions since they are only protected when there is both a biological and parent-child relationship. ${ }^{244}$ When families lack biological relationships, there are no protections for the non-traditional family. ${ }^{245}$

For example, in resolving a dispute between a non-biological father and the child's biological father, which involved conflicting presumptions of paternity under Wyoming paternity statutes, the Wyoming Supreme Court in T.L. v. C.S. ${ }^{246}$ held that absent evidence that the biological results were faulty, the biological father was entitled to judgment as a matter of law, even though the non-biological father brought the child into his home and held the child out as his own. ${ }^{247}$ In the earlier proceedings, the non-biological father was initially granted summary judgment based on the hold-out presumption. ${ }^{248}$ After the Wyoming Supreme Court overturned the summary judgment decision, the case continued to a jury trial where the jury found that the nonbiological father's presumption prevailed over the biological presumption. ${ }^{249}$

243. See Glennon, supra note 12 , at 592 .

244. See In re Guardianship of Megan N., No. B163779, 2003 WL 2119681 (Cal. Ct. App. May 22, 2003 ) (reversing a maternal grandmother's guardianship award over a child where the biological father, though never married to the child's mother, lived with the child for a short period of time and had an ongoing parent-child relationship that included an unwritten visitation agreement and child support payments, which the father continued to make to the maternal grandmother after the child's mother died).

245. The only protections that arise are when the father acknowledges biological paternity. See Stark County Soc. Servs. Bd. v. R.S. (Interest of M.Z.), 472 N.W.2d 222, 223 (N.D. 1991) (refusing to open a determination after a father stipulated to paternity in a paternity adjudication).

246. T.L. v. C.S., 975 P.2d 1065 (Wyo. 1999).

247. Id. at 1066

248. Id. (citing J.C.I. v. T.L., 917 P.2d 183 (Wyo. 1996)).

249. Id. 
The district court overturned the verdict and the non-biological father appealed. $^{250}$

On appeal, the Wyoming Supreme Court held that based on language in the paternity statute that evidence of biological paternity can only be rebutted by clear and convincing evidence, "genetic testing resolve[s] any conflict between statutory presumptions." ${ }^{251}$ While acknowledging that circumstances may exist where the child's best interests would require that an established parent-child relationship be preserved over the biological father's interests, the court held that biology is the "prevailing presumption" which can be rebutted only by attacking the genetic test results. ${ }^{252}$

In Pape v. Pape, ${ }^{253}$ the court also favored biology over the parent-child relationship when it reversed the trial court's finding that a stepfather was entitled to custody of his non-biological child after the child's mother died. There, the stepfather lived with the child for the three years preceding her mother's death and continued to reside with the child after the mother's death. ${ }^{254}$ Granting custody to the biological father, the court reaffirmed the policy that biological parents should prevail over non-biological caregivers absent proof of unfitness. ${ }^{255}$ The appellate court found that the stepfather, having "no blood relation" to the child, had no legal claim to custody of the child. ${ }^{256}$

In contrast, in two separate dependency actions, California courts recognized non-biological fathers' presumptive paternity rights based on the parent-child relationships. ${ }^{257}$ In both Nicholas $H$. and $O . B$., the courts granted custody to the fathers when the children became wards of Social Services. ${ }^{258}$ The courts relied on the fact that the fathers lived with the children and had developed parent-child relationships with the children while the biological fathers and mothers failed to adequately provide for their children. ${ }^{259}$ Only when the courts strip away the biological lens through which paternity is

250. Id.

251. Id. at 1068 .

252. Id. at 1069.

253. Pape v. Pape, 444 So. 2d 1058, 1061 (Fla. Dist Ct. App. 1984).

254. Id. at 1059.

255. Id. at 1060.

256. $I d$.

257. See Alameda County Soc. Servs. Agency v. Kimberly H. (In re Nicholas H.), 46 P.3d 932 (Cal. 2002); Monterey County Dep't of Soc. Servs. v. D.M. (In re O.B.), No. B150139, 2002 WL 596383 (Cal. Ct. App. Apr. 16, 2002).

258. See Kimberly H., 46 P.3d at 934; D.M., 2002 WL 596383, at *1.

259. See generally Kimberly H., 46 P.3d 932; D.M., 2002 WL 596383. 
traditionally viewed are they able to consider the non-traditional family's importance to the child, and, in some sense, to society.

The answer to this question [regarding whether a non-biological father could qualify as a presumed father under California's hold out presumption] is of the gravest concern to the six-year-old boy involved in this case. . . . [I]f . . the [hold out ] presumption ... was rebutted by the presumed father's admission that he is not the biological father, this child will be rendered fatherless and homeless. ${ }^{260}$

The Kinnard v. Kinnard ${ }^{261}$ court also looked beyond the biological truth when it allowed a stepmother to share custody of her stepchildren with their biological father where the father and stepmother married while the child was in kindergarten and it was determined by the court that it would be detrimental to the child if the stepmother were removed from the child's life based on their parent-child relationship. Classifying the stepmother as a psychological parent, the court reasoned that if the stepmother had been biologically related to the child, the father would lose all custody rights to the child. ${ }^{262}$ The court examined the child's and stepmother's intentions to maintain a parent-child relationship, holding that a psychological parent relationship requires that both the parent's and child's interests be considered. ${ }^{263}$

When paternity decisions are based on the parental relationship rather than the biological relationship as the Nicholas H., O.B., and Kinnard courts did in determining reunification ${ }^{264}$ and custody rights, the child's family and parental relationships are legitimized and biology loses its legal importance. While biological paternity was not at issue in those cases, the role of the nontraditional family and non-biological father in the children's lives was. When the perceived biological truth is not at issue, the court's consideration focuses on what should always be the focus, the child's interest in obtaining a loving, stable parent-child relationship and family.

\section{A Child-Centered Standard}

Biology as a basis for identifying fathers and defining legally-protected families is flawed. It creates a narrow vision of what a family or father is or

260. Kimberly H., 46 P.3d at 933-34.

261. Kinnard v. Kinnard, 43 P.3d 150, 153-54 (Alaska 2002).

262. Id. at 154

263. Id.

264. Reunification is an issue in dependency cases. William Wesley Patton, Searching for the Proper Role of Children's Counsel in California Dependency Cases: Or the Answer to the Riddle of the Dependency Sphinx, 1 J. CENTER FOR CHILD \& CTS. 21 (1999). 
could be. Rather than limiting fatherhood to biology, and families to those actual or perceived biological relationships, the law must acknowledge that children, as the center of the family and the catalyst that creates fathers, need relationships, not genetics. ${ }^{265}$

To facilitate the identity of fathers and definition of families, a childcentered approach must prevail. Families must be legitimized without deference to biological ties, living arrangements and timing of the conception of the parent-child relationship. ${ }^{266}$ That can only be achieved by a childcentered approach that focuses on the relationships of adults with their children, biological or otherwise, rather than with the other adults in the child's life. ${ }^{267}$

Rather than discounting the non-traditional family, parentage laws should be flexible enough so that all families, including those that are not based in biology or marriage, are given the same protections. Adopting a childcentered approach to families would allow the courts to consider the relationships that make up the family over the form of the family.

In addition, fathers must be recognized, not for their genetic contribution to the child's creation, but rather for their emotional, psychological and financial contribution to the child. ${ }^{268}$

[T]he most important moral requirement at stake here is that adults care and provide for children. Morality does not require that those children be the adults' biological offspring, and, as we have seen, law which bases parental rights and duties on biological relationship alone is not notably effective at inducing responsible behavior. ${ }^{269}$

Therefore, the parent-child relationship has to be defined by the parent's role in the child's life and the child's dependence on the parent to provide that role. While the parental role has to be more than just a financial one, parents will be more willing to pay child support and to take an active role in their children's lives because they will have chosen the parental role, rather than having been forced into it as occurs under current biology-based paternity laws. ${ }^{270}$

265. Bioethicist, Thomas Murray, says "policy across domains should be informed by the recognition that "the flourishing of parents and children is intertwined; that by doing what is loving for their children, parents experience profound satisfactions and develop virtues that promote their own flourishing as well.'” Anderlik \& Rothstein, supra note 13, at 225.

266. See Harris, supra note 63, at 461.

267. See Woodhouse, supra note 59, at 1753.

268. See Harris, supra note 63, at 480.

269. Harris, supra note 63 , at 485 .

270. See Bartlett, supra note 41 , at 951 ; Scott \& Scott, supra note 14 , at 2450 . The argument that 
Once those attachments are made, the end of the parental relationship by divorce or separation does not overcome the child's relationships with his parents. ${ }^{271}$ Arguably, a biological truth could affect the perceptions of both the father and child on what constitutes a father and family; however, if the focus, in both parentage laws and society, is on the father's function as a parent and the family's role with respect to the children, the courts will not be faced with having to force a father to maintain a relationship with his child, regardless of the biological ties they do or do not share. ${ }^{272}$

This child-centered approach is consistent with the law's history of promoting stability, certainty, and accuracy, where stability was generally favored over accuracy in parentage determinations. ${ }^{273}$ Where biology professes to establish certainty in parentage, it actually creates uncertainty in both families and fatherhood, whereas a child-centered approach creates certainty by acknowledging the father's actions toward the child. ${ }^{274}$

In addition, stability is ensured in that once the parent-child relationship is established, the child can rely on its permanence, not subject to biological or marital attack. ${ }^{275}$ Finally, accuracy is also created by the child-centered approach because it legitimizes the essence of parents and families rather than an idealistic vision that excludes families that are different in form but actually function the same in the key ingredient - the relationships with the child. ${ }^{276}$

allowing a non-biological father to maintain parental rights after therelationship with the mother ends limits the mother's freedom is unpersuasive since she is the one who "invite[d]" the father into her child's life and encouraged the parent-child relationship. See Woodhouse, supra note 59, at 1846-47. This would be the same argument for a biological father with whom the woman no longer wishes to maintain a relationship. If that were the case, there would be no question that the biological father who maintained a relationship or even tried to do so would be allowed to pursue his relationship with the child. It is only when the parents are unmarried and the father lacks a biological connection to the child that the courts, legislators and society see fit to distinguish the child's familial relationship to her father.

271. See Garrison, supra note 14 , at 887 ; Glennon, supra note 128 , at 278; Woodhouse, supra note 59, at 1762; see also Kisthardt, supra note 73, at 641.

272. See Rogers, supra note 22, at 1172-73.

273. See Anderlik \& Rothstein, supra note 13, at 222.

274. See Woodhouse, supra note 59, at 1823.

275. "When substitute social parents have not formally established parental status, however, noncustodial biological parents are far more likely to succeed in asserting parental rights." Scott \& Scott, supra note 14, at 2470-71 (emphasis added). "Parents are not fungible players in their children's lives, and disruption of the parent-child bond is costly to children's psychological health. For these reasons, both child-development experts and policy analysts argue for protecting established parent-child relationships outside of the intact family." Id. at 2445.

276. See Bartlett, supra note 41, at 944; Garrison, supra note 14, at 922; Scott \& Scott, supra note 14, at 2434. “'In order to develop - intellectually, emotionally, socially, and morally—a child requires participation in progressively more complex reciprocal activity, on a regular basis over an extended period 
Therefore, parentage laws should protect the child's relationships with her parents, identifying fathers and defining families by those relationships, which, akin to fiduciary relationships in the law, encourage the parent to continue the child-parent relationship regardless of the termination of the relationship between the adults. ${ }^{277}$ In a child-centered parentage approach, non-traditional families will function based on the child's relationships with each parent without fear that the family or parental role will end with the adult relationships. ${ }^{278}$ "[T] he child's view of commitment is less formal than functional. The child's experience of marriage is not in the ceremony but in the building of the nest." ${ }^{279}$

The child's preference for the function of the family is true whether there is a biological connection to the parents or not, as the child's only experience is with the family unit as they enter it, not as it existed during the courting, newlywed or pre-children periods or as it is portrayed in fairytales or sitcoms. Therefore, even if there was a non-functioning family unit before the child's birth, if the family functions effectively after her birth, regardless of the living arrangements of the parents and child, the child will form a familial relationship with both parents.

In addition, under a child-centered approach, the child's interests are preferred to the adults' interests. Allowing a mother to terminate a fatherchild relationship when her relationship with the father ends would be impermissible because the child's interests lie in protecting each parental relationship, irrespective of the relationship between the adults. ${ }^{280}$

While critics of the child-centered approach's preference for parent-child relationships argue that a parental relationship is difficult to evaluate, the legislature can enact presumptions that allow the courts to weigh objective factors such as the child's age when the father-child relationship was commenced, the strength of that relationship, and the child's reliance on that

in the child's life, with one or more persons with whom the child develops a strong, mutual, irrational, emotional attachment and who is committed to the child's well-being and development, preferably for life." Urie Bronfenbrenner, Discovering What Families Do, in Rebuilding the Nest: A New Commitment to the American Family 27, 29 (David Blankenhorn et al. eds., 1990) (quoted by Woodhouse, supra note 59, at 1766).

277. See Glennon, supra note 128, at 282.

278. $I d$.

279. Woodhouse, supra note 59, at 1848.

280. See Garrison, supra note 91, at 464-65 (noting that "[e]ven when the parent-child relationship [is] 'poor' or had deteriorated," children will choose to maintain the relationship rather than end it because once the parent-child relationship is established, it is not easily destroyed) (citing JUDITH S. WALLERST EIN \& Joan Berlin Kelly, Surviving the Breakup 219 (1980)); see also Woodhouse, supra note 59, at 1766. 
relationship in developing her own identity and the identity of her family. ${ }^{281}$ In addition, even though a child-centered approach has the capability of creating multiple parental relationships, children already have multiple relationships as a result of divorce, remarriage, step-families and extended families, all of which are legally recognized and protected under parentage laws. $^{282}$

\section{Conclusion}

A child can identify her father by the color of his hair, the smell of his cologne or the sound of his laugh - not by the patterns of his genes. Yet parentage laws do just that when they focus on a father and child's biological ties rather than their psychological ones. In doing so, parentage laws favor nature over nurture. Children do the opposite. This is one of those times where children are right.

While biology can determine with near certainty the source of the sperm that fertilized the egg that gestated into the child, it is the people that cared for the child, nurtured her growth and encouraged her development who parented the person she becomes. Furthermore, as a biological-relationship does not guarantee a parent-child relationship, limiting fathers and families to biological ties does not protect the child's interest in obtaining stable, lasting parental and familial relationships.

In contrast, a child-centered approach, which relies on the parent-child relationship to establish a family, regardless of the absence of corresponding biological ties, allows the child to define her parents and family based on the lasting role they play in her life. It focuses on the child's relationships and interests over the parents'. As a result, the child's family does not have to start at birth or the marriage of her parents, nor does it have to end when her parents' adult-adult relationship ends. Likewise, a father is not limited to the man who provided half of the child's genetic make-up. He can be the man who, through a parent-child relationship, provided her with emotional, psychological and financial support, regardless of his genes.

281. See Harris, supra note 63, at 481, 482; Niccol Kording, The Day the Family Dies: The Bald Eagle, DNA, and Money Privilege in Paternity Fraud Legislation and Common Law Paternity Decisions, J. LAW \& SOCIAL CHANGE _ (forthcoming 2004) (proposing a statute limiting the right to genetic testing when a parent-child relationship exists and setting forth civil and criminal penalties for self-help genetic testing and disclosure of the results of illegal genetic testing, as well as assisting in the procurement or disclosure of test results).

282. See Harris, supra note 63, at $482-83$. 
One hundred years from now it will not matter what kind of car I drove, what genes I had, what my child's last name was, what house my child's father lived in - but the world may be a little better if the parentage system focused more on the parent who was important in the life of a child rather than the one who had the same genes. 